\title{
Does Sustainability Require a New Theory of Property Rights?
}

\author{
Carl J. Circo*
}

Cursed be thy stones for thus deceiving me. ${ }^{1}$

\section{INTRODUCTION}

Will future generations damn us for what we have valued most? Does our reverence for private property threaten "the ability of the future generations to meet their own needs?"2 Will our growing commitment to sustainability force us to restrict individual property rights or, more happily, will it teach us that ecological efficiency is the most effective capitalist strategy?

In pursuing these questions, this Article examines the potential conflicts between sustainability theory and property theory. Part II briefly surveys sustainability concepts, both in theory and in practice. It begins by identifying three main theoretical strains: resource conservation; generational justice; and social justice. The remainder of Part II examines a few specific applications of sustainability to illustrate how sustainability objectives may conflict with common understandings of private property rights in contemporary U.S. society. To put the potential conflict between sustainability and property rights in broad conceptual contexts, Part III contrasts selected theoretical themes from

\footnotetext{
* Associate Professor of Law, University of Arkansas School of Law. I owe special thanks to my colleagues, Professor Stephen Sheppard and Professor Ned Snow, who thoughtfully reviewed drafts of this Article and made many valuable substantive and editorial suggestions. I also acknowledge the contribution of Jon Davis, a 2008 graduate of the University of Arkansas School of Law, whose independent research project helped me to explore the relationship between sustainability and contemporary property theories. Finally, Michael Thompson, a third-year student at the University of Arkansas School of Law, worked diligently and efficiently to edit footnotes.

1. William Shakespeare, A Midsummer Night's Dream, in The Complete Works 351, 373 (Stanley Wells \& Gary Taylor gen. eds., 1986). With this curse, Shakespeare's comic character, Bottom, speaking in an amusingly short play within a play, discovered the same apparent dilemma that bedevils sustainable development: human design and labor may promise happiness, yet ultimately deliver despair. Bottom came to a simple stone wall believing in vain that it would yield a blissful glimpse of his beloved Thisbe.

2. WORLD COMM’N ON ENV’T \& DEv, OUR COMMON FUTURE 8 (1987)
} 
three competing property perspectives, giving particular attention to those most relevant to sustainability programs. The three theoretical themes - here designated traditional, economic, and relational-provide different capacities to accommodate sustainability. Part IV samples property theory and sustainability theory as reflected in a few contemporary legislative and judicial decisions. Part V considers what concessions sustainability may eventually demand of property theory.

In the final analysis, the extent to which sustainability requires a new theory of property rights for the United States depends both on what model of sustainability ultimately prevails in this country and on the degree to which property rights doctrine clings to traditional and economic notions. Traditional and economic theories of property will accommodate mild versions of sustainability, but not stronger ones. While the principles that inform traditional theories should permit expanded limits on private property rights in the interest of conserving resources both for today and, to a point, for the protection of remote generations, they do not easily adapt to the social justice objectives of the international sustainability movement. Economic calculations also take into account the value of resource conservation for the present and into the near future, but their ability to apply the calculus to more remote generations depends on the skill of environmental economists to develop compelling new tools to value human welfare over time. Moreover, the social justice objectives of sustainability seem intrinsically incompatible with the leading versions of economic analysis. The net result may well be that U.S. concepts of private property cannot fully conform to sustainability without a distinct shift to relational perspectives that currently exist only at the fringes of property theory as applied in this country.

\section{SustainABILITY In THeORY AND PRACTICE}

\section{A. Sustainability Theory}

Many sustainability advocates have noted the fluid attributes of the ecological concept they advance. ${ }^{3}$ Some even argue that the language of sustainability often operates merely as political rhetoric without

3. See, e.g., SteVen C. Hackett, EnVironmental and NATURAl Resources Economics: THEORY, POLICY, AND THE SUSTAINABLE SOCIETY 391 (3d ed. 2006) ("The concept of sustainable development is broad and has come to mean different things to different people."); Michael Redclift, Sustainable Development: Concepts, Contradictions, and Conflicts, in FOOD FOR THE FUTURE: CONDITIONS AND CONTRADICTIONS OF SUSTAINABILITY 169, 170-71 (Patricia Allen ed., 1993). 
substance. ${ }^{4}$ To some, sustainability primarily refers to energy efficiency ${ }^{5}$ or to the slightly broader principles of efficient resource conservation. ${ }^{6}$ To others, sustainability requires radical changes in our social and

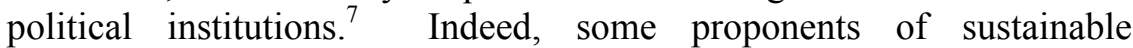
development argue for "socially just development world-wide" that "should attempt to address important social and political issues related to the inequitable allocation of the world's resources." 9 Still others envision sustainability as a fundamental human right. ${ }^{10}$

As a prelude to an analysis of the relationship between sustainability and property rights under U.S. law, the discussion that follows briefly surveys alternative theoretical perspectives from the sustainability literature. In the interest of maintaining a manageable framework for the ultimate evaluation in Part V, this overview deliberately ignores some of the subtle differences reflected in the extensive literature on sustainability to arrive at three contrasting theoretical models: resource conservation, generational justice, and social justice. Each model is introduced below in the order of their increasing potential to threaten private property rights.

\section{Resource Conservation}

Conventional environmentalism provides the essential theory for resource conservation. From this perspective, ecologically sustainable actions are both utilitarian and ethical in an a priori sense. As a purely utilitarian matter, the theory holds that society should maximize the value of natural resources for the common good by using those resources

4. Philip R. Berke \& Maria Manta Conroy, Are We Planning for Sustainable Development? An Evolution of 30 Comprehensive Plans, 66 J. AM. PLANNING Ass'N 21, 22 (2000).

5. See, e.g., Charles J. Kibert, Sustainable Construction: Green Building Design AND DELIVERY 1-3 (2005) (discussing depletion of oil reserves and the cost of fossil-fuel and natural gas intensive buildings).

6. See, e.g., id. at 9-12 (discussing sustainable construction); HACKETT, supra note 3, at 403 (stating that sustainability focuses on the future).

7. See, e.g., HACKETT, supra note 3, at 327-28, 398-99 (discussing the integration of "social justice, poverty alleviation, and environmental preservation and restoration").

8. Nancy J. King \& Brian J. King, Creating Incentives for Sustainable Buildings: A Comparative Law Approach Featuring the United States and the European Union, 23 VA. ENVTL. L.J. 397, 400 (2005) (quoting Paul Shrivastava \& Stuart Hart, Creating Sustainable Corporations, 4 BuS. STRATEGY \& ENV'T 154, 155 (1995)).

9. Id. at 401 .

10. See Dominic McGoldrick, Sustainable Development and Human Rights: An Integrated Conception, 45 INT'L \& COMP. L.Q. 796, 798 (1996) (noting that protection of human rights was the first principle of the UN Conference on Environment and Development's Rio Declaration). 
efficiently and without gratuitous waste or contamination. ${ }^{11}$ In an ethical sense, sustainability as conservation may reflect an intuitive respect for nature that stems from a fundamental preference for resource protection and preservation. ${ }^{12}$ That theory may take its foundation either from traditional cultural ${ }^{13}$ and religious ${ }^{14}$ beliefs or from a secular value system. $^{15}$

The utilitarian and ethical variations on this theoretical approach matter in limited ways. The utilitarian may argue that society should embrace sustainable development to the extent it can do so without incurring countervailing costs, which probably only refers to those costs that a sustainability program imposes on a particular local, regional, or national society. ${ }^{16}$ To the environmental ethicist sustainability is, at some level, an absolute virtue that overrides social cost. ${ }^{17}$ For example, it may be morally wrong for one social group to exhaust a finite and irreplaceable resource even if the benefits to that group are significant and the damage to other social groups is indeterminate. Similarly, an ethical model might condemn a decision to exploit a natural resource that has significant aesthetic value.

\section{Generational Justice}

While conventional environmentalism considers the interests of future generations, some theoretical writings on the contemporary sustainability movement elevate this concern to a central position. ${ }^{18} \mathrm{~A}$

11. See HACKETT, supra note 3, at 325 ("[W]e can think of sustainable development as providing the support necessary for the functional elements of economy, community, and environment to achieve their full potential.").

12. See, e.g., Timothy Beatley \& Richard Collins, Smart Growth and Beyond: Transitioning to a Sustainable Society, 19 VA. ENVTL. L.J. 287, 296-301 (2000) (asserting the intrinsic value of undeveloped land and discussing growing concern over our ecological footprint).

13. See, e.g., HACKETT, supra note 3, at 323 ("Many cultures over the course of human history have recognized the need for harmony between their economy, community, and environment.").

14. See e.g., J. Ronald Engel, Introduction to ETHICS OF ENVIRONMENT AND DEVELOPMENT 12-14 (J. Ronald Engel \& Joan Gibb Engel eds., 1990) (discussing multiple religious theories).

15. See Samuel R. Staley, Institutional Considerations for Sustainable Development Policy Implementation: A U.S. Case Study, 24 Prop. MGMT. 232, 233-36 (2006) (discussing institutional and governmental effects on sustainability).

16. See Engel, supra note 14, at 10 (referring to "the common association of "sustainable development' with the limited goal of resource conservation-growth with equity" as "the dominant Western paradigm").

17. See Rajni Kothari, Environment, Technology, and Ethics, in ETHICS OF ENVIRONMENT AND DEVELOPMENT, supra note 14, at 27, 33 (concluding that "if there is to be a moral imperative for sustainable development, there needs to be a sense of sanctity about the Earth").

18. See Edith Brown Weiss, Intergenerational Equity: A Legal Framework for Global Environmental Change, in ENVIRONMENTAL CHANGE AND INTERNATIONAL LAW: NEW 
conventional environmentalist might accept generational relativismreasoning that development may proceed as long as it minimizes environmental damage in light of the demographic, economic, and technical circumstances prevailing at the time and place the development activity occurs. By contrast, generational justice asserts that each generation must preserve natural resources at least to the extent necessary for future generations to benefit on a relatively equal basis with the current generation. ${ }^{19}$

The most articulate statements of generational justice use the concept of natural capital. Those scholars argue that natural capitalism should constitute a stable account for each generation to use but not exhaust or damage. ${ }^{20}$ This framework literally adopts Thomas Jefferson's civil law property metaphor "that the earth belongs in usufruct to the living." 11 This perspective insists that each generation must maintain not only the earth's natural resources but also its capacity to service human activity. Sustainability utterly depends on natural capital, which is fragile and finite:

The natural capital stock usually is divided into three categories: non-renewable resources, such as mineral resources; the finite capacity of the natural system to produce "renewable resources" such as food crops and water supply; and the capacity of natural systems to absorb the emissions and pollutants that arise from human actions without side effects that imply heavy costs passed onto future generations. Natural capital includes all natural assets; humans can alter it, and humans can enhance its reproduction, but humans cannot create it. ${ }^{22}$

Whether or not those who advocate sustainability based on generational justice expressly use natural capital terminology, the central point is the same: The earth has finite resources and capacities that no generation has any right to take away from any future generation. In its strongest form, generational justice may demand far greater restraint than conventional environmentalism. For example, the traditional environmentalist may

Challenges AND Dimensions (Edith Brown Weiss ed., 1991), reprinted in RichaRd L. ReVesZ, Foundations of ENVIRONMENTAL LAW AND POLICY 309, 309-12 (Oxford Univ. Press 1997) (stating that conservation of resources is a basis of intergenerational equity and sustainability).

19. Id.

20. See generally Richard W. England, Should We Pursue Measurement of the Natural Capital Stock?, 27 ECOL. ECON. 257 (1998); Jan Geldrop \& Cees Withagen, Natural Capital and Sustainability, 32 ECOL. ECON. 445 (2000).

21. Letter from Thomas Jefferson to James Madison (Sept. 6, 1789), in 7 THE WRITINGS OF THOMAS JEFFERSON, at 454 (Albert Ellery Bergh ed., 1907) (emphasis in original).

22. Yosef Jabareen, A Knowledge Map for Describing Variegated and Conflict Domains of Sustainable Development, 47 J. EnVTL. Plan. \& MGMT. 623, 628 (2004) (citation omitted). 
approve using exhaustible natural resources, such as minerals, if done efficiently and without contaminating other natural resources. ${ }^{23}$ But generational justice may dictate that a society should only use exhaustible natural resources if it can create or provide their functionaland perhaps even their aesthetic-equivalent for the benefit of future generations through technology or some other means. ${ }^{24}$ As suggested by recurring references to the resources of the earth as a whole, generational justice often implies a global perspective, although globalism is not its defining characteristic. ${ }^{25}$

\section{Social Justice}

Generational justice aims to expand the human instinct for familial preservation by taking into account the human race as it extends to eras beyond any living individual's personal experience. But it does not necessarily insist on equality for the individuals comprising either the current generation or any distant one. By contrast, the social justice model of sustainability seeks an eventual redistribution of the earth's resources to achieve some minimal level of allocation to all individuals. ${ }^{26}$ The most radical form of sustainability incorporates the tenets of global social justice. Therefore, the object is not only to preserve the earth's resources for future generations, but also to alter social institutions so in the future all societies and individuals will benefit from both natural and other resources more equitably. ${ }^{27}$

The central argument for infusing sustainability with social justice is that current social institutions cannot be sustained indefinitely. ${ }^{28}$ While proponents of this approach do not always explicitly state the

23. See, e.g., WolfGAng SACHS, Planet DiAlectics: ExPlORATIONS IN ENVIRONMENT AND DEVELOPMENT 27-42 (1999) (criticizing an environmental perspective that gives priority to a continuing right to development).

24. See Geldrop \& Withagen, supra note 20, at 446-47 (discussing use of substitute products and technological innovation to ensure sustainable development).

25. See, e.g., Weiss, supra note 18, at 309 (indicating that "[s]ustainable development rests on a commitment to equity with future generations" and reflects the principle that "each generation should be required to maintain the quality of the planet").

26. See Arne Naess, Sustainable Development and Deep Ecology, in ETHICS OF ENVIRONMENT AND DEVELOPMENT, supra note 14, at 87, 94-96.

27. See Redclift, supra note 3, at 188-90 (stating that current thought includes more environmental considerations that influence organizations and policymakers).

28. See Henri Acselrad, Sustainability and Territory: Meaningful Practices and Material Transformations, in SUSTAINABILITY AND THE SOCIAL SCIENCES: A CROSS-DISCIPLINARY APPROACH TO INTEGRATING ENVIRONMENTAL CONSIDERATIONS INTO THEORETICAL REORIENTATION 37, 53-54 (Egon Becker \& Thomas Jahn eds., 1999) (discussing the relationship between sustainability and intergenerational justice). 
assumptions that inform this version of sustainability, their arguments frequently include a modern strain of socialist thought. ${ }^{29}$ They depart from generational justice by objecting that a trans-generational perspective alone fails to distinguish between the needs "of the global consumer class or those of the enormous masses of have-nots.", 30

But how is social justice in the form of distributive equity a matter of sustainability? Why can a society or world that is unjust in a distributive sense not continue to reproduce itself indefinitely? ${ }^{31}$ Perhaps the implicit premise to connect equity in resource allocation with sustainability is that social institutions that fail to provide for the economic needs of all will inevitably fail, presumably because pressure from those in desperate need will force change either through democratic processes or violence. ${ }^{32}$

International law expressly recognizes social justice as a basis to advance sustainability. ${ }^{33}$ Several United Nations documents advocating sustainable development espouse a global social justice rationale. For example, the Rio Declaration on Environment and Development proclaims "the essential task of eradicating poverty as an indispensable requirement for sustainable development." ${ }^{34}$ Similarly, the Johannesburg Declaration on Sustainable Development asserts that "[t]he deep fault line that divides human society between the rich and the poor and the ever-increasing gap between the developed and developing worlds pose a major threat to global prosperity, security and stability.",35

29. See generally, SACHS, supra note 23 , at $159-74$.

30. Id. at 160. See also Andrew Harding, Access to Environmental Justice: Some Introductory Perspectives, in AcCess to EnVIRONMENTAL Justice: A COMPARATIVE STUdy 1, 3-11 (Andrew Harding ed., 2007) (discussing inequality in accessing gateways to environmental justice); Vicki Bean, What's Fairness Got to do with it?: Environmental Justice and the Siting of Locally Undesirable Land Uses, in REVESZ, supra note 18, at 112, 112-17 (discussing how discrimination can affect the siting of locally unwanted land use).

31. See Acselrad, supra note 28 , at 55 (suggesting that reproducing indefinitely may be ethically wrong).

32. See Naess, supra note 26, at 95 (explaining that if the lifestyle of "the rich power elites in poor countries" does not change, the rich will be judged as "ecological and ethical misfits and violent reactions will result").

33. See McGoldrick, supra note 10, at 798.

34. United Nations Conference of Environment and Development, Rio de Janeiro, Braz., June 3-14, 1992, Rio Declaration on Environment and Development, 9 5, U.N. Doc. A/CONF/151/26 (1992); see also John R. Nolon, Comparative Land Use Law: Patterns of Sustainability, 37 URB. LAW. 807, 815-18 (2005).

35. World Summit on Sustainable Development, Johannesburg, S. Afr., Aug. 26-Sept. 4, 2002, Report, $\uparrow 12$, U.N. Doc A/CONF.199/20 (2002) [hereinafter Report on Sustainable Development]. 


\section{B. Sustainability in Practice-A Sampling of Initiatives Affecting Property Rights}

Commentators frequently note the lack of agreement on how best to implement sustainability. ${ }^{36}$ At least in part, this is inevitable because sustainability carries many different meanings. ${ }^{37}$ Indeed, some of the most prominent documents of the sustainability movement offer notoriously vague outlines of the specific actions required to achieve sustainability. The Plan of Implementation of the World Summit on Sustainable Development demonstrates this problem by offering an extensive list of broad goals that, by necessity, require interpretation by individual countries and agencies. ${ }^{38}$

Will the global sustainability movement eventually lead to restrictions on private property rights as currently recognized in the United States? Several economic development strategies suggest the possibility. Long-standing proposals to reduce harmful industrial emissions, for example, include standards that could generate significant governmental controls over the use and development of private property, such as coal reserves. ${ }^{39}$ Similarly, calls to preserve natural capital involve significant limits on the property rights of those who own land or the rights to natural resources. ${ }^{40}$

This part notes just a few examples of regulations and restrictions adopted or proposed in the name of sustainability that could, depending on one's theoretical framework, conflict with private property rights. The goal here is not to catalogue points of conflict, but merely to place the potential tension between sustainability and property rights in a concrete context. Examples taken from land use controls and forestry management will serve the purpose.

\section{Applying Sustainability Theory to Land Use}

In the United States, the sustainability movement has already spawned land use regulations. The three examples mentioned here show

36. See, e.g., McGoldrick, supra note 10, at 798-99; Acselrad, supra note 28, at 49.

37. Redclift, supra note 3, at 170-71.

38. See generally Report on Sustainable Development, supra note 35, at Annex 9-71.

39. See, e.g., Bruce A. ACKerman \& William T. HASSler, CleAn CoAl/DirTy Air (1981), as reprinted in REVESZ, supra note 18, at 193, 193-200 (analyzing the effects of government regulations on coal mining companies).

40. See, e.g., Beatley \& Collins, supra note 12, at 312-14 (suggesting that the United States should develop a "comprehensive large-scale integrated system of protected lands" to preserve natural capital). 
that sustainability initiatives will sometimes clash with private property interests.

\section{a. Sustainable Construction Codes}

Concern for energy efficiency, which is a consistent theme of the sustainable development movement, has led to increasing attention on data showing the impact the built environment has on energy consumption and climate change. ${ }^{41}$ Potential improvements in the design, construction, use, and final disposition of buildings create opportunities for significantly increasing energy efficiency and reducing greenhouse gas emissions on a global basis. ${ }^{42}$ Among the most farreaching ideas are proposals for buildings that generate as much energy as they use (zero-energy buildings) and even buildings that produce surplus energy (energy-plus buildings). ${ }^{43}$

These considerations have led several state and local governments to enact laws encouraging or requiring real estate developers and building owners to adopt more sustainable design and construction practices. ${ }^{44}$ While many of the original sustainable construction (commonly called green building) initiatives relied primarily on incentives to promote voluntary compliance with sustainable construction standards in the private sector, a growing number of cities are moving toward requiring private projects to meet minimum green building standards. ${ }^{45} \mathrm{~A}$ recent Boston ordinance applies to all new buildings in excess of 50,000 square feet of floor area, as well as to rehabilitation projects of over 100,000 square feet. ${ }^{46}$ The District of Columbia also imposes green building standards on many private projects, ${ }^{47}$ and other major cities have mandatory standards under consideration. ${ }^{48}$ There are at least some early

41. PekKa Huovila et al., U.N. Environment Programme, Buildings and Climate Change: StATUs, Challenges AND OpPortunities 1 (2007).

42. See KIBERT, supra note 5, at 7-14.

43. HuOVILA, supra note 41, at 26-27.

44. For an overview of recent green building regulations see Carl J. Circo, Using Mandates and Incentives to Promote Sustainable Construction and Green Building Projects in the Private Sector: A Call for More State Land Use Policy Initiatives, 112 PENN ST. L. REV. 731, 751-62 (2008).

45. See Jess W. Abair, Green Buildings: What It Means To Be "Green" and the Evolution of Green Building Laws, 40 URB. LAW. 623, 628-32 (2008) (discussing local laws that set minimum standards for green buildings).

46. Boston, Mass., Mun. Code $\S 37-3$ (2007) (referencing Boston, Mass., Mun. Code $\S$ 80B (1996)).

47. D.C., CODE $\S \S 6-1451.01-11$ (2008).

48. See Abair, supra note 45, at 630-32 (noting proposed local laws in Los Angeles and San Francisco); Circo, supra note 44, at 759-62 (referencing similar discussions in Santa Monica and Chicago). 
signs of skepticism in the real estate development community that may fuel significant resistance when green building initiatives threaten profit margins. ${ }^{49}$

\section{b. Growth Management-The Oregon Experience}

Using an approach that is less direct than a sustainable construction building code, Oregon's growth management strategy incorporates a sustainable development motif into the state's smart growth controls. The smart growth, or anti-sprawl, approach to land use controls, while distinct from the global sustainability movement, evidences a closely related regional version of sustainability. ${ }^{50}$ As Professor Salkin has observed, smart growth concepts occur at the "dynamic intersection of land development and conservation."

Oregon has been a leader in promulgating smart growth techniques. ${ }^{52}$ An especially important feature of Oregon's system is the adoption of urban growth boundaries, which establish geographic limits to prevent development from prematurely encroaching into agricultural areas. ${ }^{53}$ Although the boundaries provide areas for urban growth, they impose state-wide growth management policies on local land use authorities for the purpose of carefully controlling urban sprawl. ${ }^{54}$ "In order for the boundary to be expanded or modified, a local government must demonstrate a need for additional urban areas that cannot be met by land already within the boundary., ${ }^{55}$

49. See, e.g., Cathy Lang Ho, Eco-Fraud: "Green Buildings" Might Not Be All They're Made Out to Be, ARChiteCtURE, July 2003, at 31 (stating that "'if green features don't make good economic sense, the design is a failure"') (quoting Greg Kiss, Brooklyn, New York-based architect); Jennifer Popovec, The Tipping Point, NAT'L ReAl Est. InVESTOR, Nov. 2006, at 25 ("68\% [of construction and real estate industry executives] said they avoided green construction because of concerns about cost. They also said lack of awareness and sketchy information on the financial benefits held them back."); Toccoa Switzer, Altruistic or Opportunistic?: Savvy Developers of Green Buildings Reduce Energy Costs, NAT'L REAL Est. InVESTOR, July 2006, at 105-06 ("the belief that green buildings cost more to build remains a major obstacle to the green building movement").

50. Proponents of smart growth "value long-range, regional considerations of sustainability over short term incremental geographically isolated actions." AMERICAN PLANNING ASSOCIATION, POLICY GUIDE ON SMART GROWTH $§ 1$ (2002), available at http://www.planning.org/ policy/guides/adopted/smartgrowth.htm.

51. Patricia E. Salkin, Squaring the Circle on Sprawl: What More Can we Do? Progress Toward Sustainable Land Use in the States, 16 WIDENER L.J. 787, 790 (2007).

52. Id. at 813 .

53. Id. at 813-14.

54. Id.

55. Id. at 814 . 
Because urban growth boundaries sometimes thwart plans to realize the economic potential of land just beyond population centers, Oregon landowners and developers have frequently challenged the burdens that this regulatory scheme imposes on property rights. ${ }^{56}$ In 2004, an Oregon ballot initiative, Measure $37,{ }^{57}$ temporarily set the state's smart growth philosophy on its head by enacting a requirement that when a landowner establishes that a land use control reduces the fair market value of property, the government must either rescind the regulation promptly or pay the landowner compensation equal to the reduction in market value. $^{58}$ Although in 2007 , Oregon voters significantly limited the scope of the 2004 initiative, ${ }^{59}$ the story of Measure 37 may suggest that aggressive sustainable development initiatives will inevitably face strong opposition from property rights advocates. ${ }^{60}$

\section{c. Local Tree Preservation Programs}

Municipal tree preservation regulations provide another simple example of applied sustainability in potential conflict with private property rights. A growing number of communities have incorporated tree preservation objectives into their land use planning. ${ }^{61}$ These regulations seek to balance the needs of current development, which frequently encourage the developer to clear naturally forested land, with a community's desire to maintain a target level of forestry resources for the enjoyment of current citizens and future generations. ${ }^{62}$ Because trees are reproducible natural resources, the benefits that they provide to a community will continue indefinitely from one generation to the next unless threatened by some external force, such as real estate development. ${ }^{63}$ Contemporary tree preservation ordinances often require

56. Id. See Haviland v. Land Conservation \& Dev. Comm'n, 609 P.2d 423, 425-27 (Or. Ct. App. 1980) (providing an example of just such a challenge).

57. See generally Or. Ballot Measure 37 (2004), superseded by Or. Ballot Measure 49 (2007) (codified in scattered sections of Or. Rev. Stat.), available at http://www.oregonvotes.org /nov62007/guide/m49_text.html.

58. Michael C. Blumm \& Erik Grafe, Enacting Libertarian Property: Oregon's Measure 37 and Its Implications, 85 DENV. U. L. REV. 279, 281 n.1 (2007).

59. See generally Ballot Measure 49, supra note 57.

60. For a discussion of how this conflict played out in Oregon, see generally David J. Boulanger, Comment, The Battle Over Property Rights in Oregon: Measures 37 and 49 and the Need for Sustainable Land Use Planning, 45 WiLlameTTE L. REV. 313 (2008).

61. See generally Christopher J. Duerksen, Tree and Vegetation Protection, in RATHKOPF's The LAW OF ZONING AND PLANNING $\S \S$ 20:1-82 (2007) (comprehensively discussing tree preservation ordinances).

62. Id. § 20:1.

63. See generally id. $\S \S 20: 3-7$ (stating that trees serve a valid "public purpose" by contributing 
developers to retain a specified proportion of existing trees ${ }^{64}$ or to replace trees that developers remove to make way for buildings and infrastructure. $^{65}$ Once again, landowner and developer lawsuits confirm that regulations of this kind threaten U.S. concepts of private property. ${ }^{66}$

\section{Applying Sustainability Theory to the U.S. Timber Industry}

Sustainable development is not limited to real estate projects. Much of the sustainability agenda seeks to alter industrial and commercial practices that exploit the world's natural capital. The timber industry provides one of the clearest examples. Commercial logging companies sometimes use business strategies, such as clear cutting, that are unsustainable in two distinct senses. First, while forests are renewable natural resources, logging activities must be deliberately managed if forests are to provide for the needs of each generation without interfering with the ability of future generations to satisfy their own needs. Second, the earth's continuing ability to absorb $\mathrm{CO}_{2}$ emissions depends on the sustainability of forests throughout the world. Indeed, forests provide an especially interesting target for sustainability practices because they provide high-value resources for economic development purposes, contribute significantly to the earth's carrying capacity, support biodiversity, offer treasured public recreation, and have inherent aesthetic value.

Although the most highly publicized proposals call for international action to protect the earth's forests, especially in tropical areas outside of the United States, sustainable development theory also suggests an argument for more sustainable management practices wherever strategic forests exist, including within the United States. Even though Congress has acted repeatedly over the past century to protect and preserve

to the "beauty and attractiveness of our communities," providing a "protective physical and psychological barrier between pedestrians and traffic," and reducing the "impact of wind" among other benefits).

64. Id. $\$ 20: 58$.

65. Id. $\$ 20: 60$.

66. Ruthmarie Shea, Whose Tree Is It Anyway? A Case of First Impression, 77 U. DET. MERCY L. REv. 579, 583 (2000); see Corrigan v. City of Scottsdale, 720 P.2d 513, 518 (Ariz. 1986) (declaring zoning ordinance unconstitutional); Allingham v. City of Seattle, 749 P.2d 160, 163-64 (Wash. 1988) (en banc) (holding regulation was an unconstitutional taking), amended by 757 P.2d 533 (Wash. 1988), overruled in part by Presbytery of Seattle v. King County, 787 P.2d 907 (Wash. 1990). But see Glisson v. Alachua County, 558 So.2d 1030, 1038 (Fla. Dist. Ct. App. 1990) (land use regulations do not amount to an unconstitutional taking); Pecora v. Gossin, 356 N.Y.S.2d 505 (N.Y. Sup. Ct. 1974) (holding denial of excavation permit on land reserved for residential use to be "not confiscatory"), aff'd 370 N.Y.S.2d 281 (N.Y. App. Div. 1975). 
national forests, "the majority of forestry is not required to be sustainable because most forests in this country are privately owned and therefore outside the scope of federal multiple-use sustained-yield requirements. ${ }^{\prime 67}$ Applying global sustainability principles in light of prevailing forestry practices in Virginia, one article proposed state legislation requiring the timber industry and private landowners in that state to adopt more sustainable forestry management practices. ${ }^{68}$ What justifies such apparently intrusive restrictions on the rights of private property? "The state has a substantial interest in ensuring an adequate supply of timber for the future, in addition to equally important environmental protection justifications, including the reduction of greenhouse gases."69

\section{PROPERTY THEORIES}

A rich and evolving body of scholarly work documents the history and development of property theory in the U.S. legal system. ${ }^{70}$ Because the theoretical scholarship on property spans centuries, ${ }^{71}$ it is not practical to examine in detail how sustainability may conflict with every competing theory of property. For that reason, this part presents sketches of several leading themes, derived from three broad categories of theoretical work, selected because they prove especially useful for exploring the potential tension between sustainability and contemporary notions of private property rights in the United States. Recognizing that the sustainability movement is a natural outgrowth of environmentalism, this part pays particular attention to property law concepts frequently invoked to achieve or assess environmental objectives, such as redressing pollution and protecting natural resources.

In recognition that economic analysis holds a central place in contemporary property theory in this country, ${ }^{72}$ the discussion that follows divides the contrasting concepts along a rough chronology related to the emergence of economic analysis as the leading theory

67. Robert Jackson Allen, Sustainable Forestry in Virginia: Opportunities for Overdue Legislation and Options for Private Landowners, 7 APPALACHIAN J.L. 1, 4 (2007).

68. Id. at 30-31.

69. Id. at 31 .

70. See generally Perspectives on Property LaW (Robert C. Ellickson, Carol M. Rose, \& Bruce A. Ackerman eds., 2d ed. 2002); A Property ANTHOLOGY (Richard H. Chused ed., 1993)

71. See generally Stuart Banner, Transitions between Property Regimes, 31 J. Legal STUD. 359 (2002); Carol M. Rose, Canons of Property Talk, or, Blackstone's Anxiety, 108 YALE L.J. 601 (1998); Gerald B. Wetlaufer, Systems of Belief in Modern American Law: A View from Century's End, 49 AM. U. L. ReV. 1 (1999).

72. See Rose, supra note 71, at 618-19 (discussing the role of economic analysis in property law). 
among U.S. property scholars. Accordingly, it first takes up themes derived from traditional theories that were well formed in the legal literature before economic analysis achieved its current status. Next it surveys themes from the mainstream law and economics literature that are especially important to consider in light of the sustainability movement. Finally, on a highly selective basis, it reviews a few alternative themes in property theory that came to the fore only after the emergence of contemporary economic analysis. This third, and final, sketch highlights ethical perspectives that are especially pertinent to the most ambitious sustainability theories. While reducing centuries of property theory to just three general categories requires simplification, the technique is not novel, ${ }^{73}$ and it allows sufficient conceptualization for the purpose at hand.

\section{A. Selected Themes from Traditional Theories of Property}

Conventionally, U.S. law has treated property as a fundamental individual right to be protected by government. ${ }^{74}$ As the brief review that follows shows, several related political philosophies contributed to this individual rights approach. What unites the traditional theories is an ethical perspective that attributes intrinsic value to individual dominion over private property. That value may stem from traditions of Western religions, ${ }^{75}$ the related tenets of natural law in Western philosophy, ${ }^{76}$ or more simply from the utilitarian intuition that private property is essential for human happiness in a democratic society. ${ }^{77}$ In truth, all of these notions work together to support the conventional view. Traditional theories produce a strong commitment for government to recognize and protect an individual's right to acquire property, especially

73. See Robert C. Ellickson, Property in Land, 102 YALE L.J. 1315, 1323-24 (1993) (contrasting the regimes of open-access property, group property, and individual property); Rose, supra note 71, at 602-03 (grouping property theories into three contrasting strategies - the doctrinalist, the utilitarian, and the critical); Joseph William Singer, The Ownership Society and Takings of Property: Castles, Investments, and Just Obligations, 30 HARV. ENVTL. L. REV. 309, 313-14 (2006) (categorizing property thinking into an exclusive dominion model, which he calls the castle model, the investment model, and the citizenship model).

74. See O. Lee Reed, What is "Property"?, 41 AM. Bus. L.J. 459, 473-83 (2004) (discussing property as an individual right); Carol M. Rose, Property as the Keystone Right?, 71 NOTRE DAME L. REV. 329, 332-33 (1996) (arguing that property is the most important right).

75. John Locke, for example, consistently relied on the Bible in support of his theory of property. See, e.g., John Locke, Second Treatise in Two Treatises OF Government $\S \S 25,31$, 38 (Peter Laslett ed., Cambridge Univ. Press 1960) (1690).

76. See infra notes 81-96 and accompanying text.

77. See, e.g., Rose, supra note 74, at 348-56 (discussing what Rose labels the "symbolic" and "civilizing" arguments that property is the most important of all rights). 
land, and to maintain a relatively high degree of control over the use and enjoyment of private property. Admittedly, public policy considerations that have always been evident in the common law tradition, especially in its evolving and expanding view of the police power, significantly temper the traditional ideal of individual property rights. ${ }^{78}$ But ongoing debates about the proper limits on governmental power to interfere with private property rights show that the individual rights emphasis of traditional theories continues to have much force. ${ }^{79}$

Because U.S. law derives from the common law of England, Blackstone's perspective on the institution of property offers both a logical and a customary starting point for exploring the traditional theories of property in this country. Blackstone's famous reference to an owner's absolute dominion generally comports with the centrality of individual rights in property as a common law tenet. ${ }^{80}$ Although Blackstone's account was more concerned with the content of property law than with its theoretical basis, it reflects aspects of several antecedent property theories. His ruminations on the justifications for private property incorporate the first occupancy theory, which is one of the oldest and most pragmatic explanations of the institution of private property ${ }^{81}$ and they also include a natural law analysis based on Locke's labor theory and a rudimentary utilitarianism. ${ }^{82}$ Taken together, these

78. See Vill. of Euclid v. Ambler Realty Co., 272 U.S. 365, 386-89 (1926) (the seminal case establishing the constitutionality of land use zoning); Claridge v. N.H. Wetlands Bd., 485 A.2d 287, 290-91 (N.H. 1984) (upholding the denial of a landowner's request for a fill permit necessary for development of the property); Daddario v. Cape Cod Comm'n, 780 N.E.2d 124, 130-31 (Mass. App. Ct. 2002) (upholding environmental regulations); see also Steve Sheppard, The State Interest in the Good Citizen: Constitutional Balance Between the Citizen and the Perfectionist State, 45 HASTINGS L.J. 969, 994-97 (1994) (discussing the police power).

79. See discussion infra Part IV.

80. Blackstone described the right of property as "that sole and despotic dominion which one man claims and exercises over the external things of the world, in total exclusion of the right of any other individual in the universe." 2 WiLliAM BLACKSTONE, COMMENTARIES ON THE LAWS OF ENGLAND (Edward Christian ed., 1807) (1766).

81. See Lawrence Berger, An Analysis of the Doctrine That "First in Time is First in Right", 64 NEB. L. REV. 349, 350-53 (1985) (discussing the first occupancy theory); Richard A. Epstein, Possession as the Root of Title, 13 GA. L. REV. 1221, 1238-43 (1979) (same). Although the occupancy theory arguably has as much historical significance as Locke's labor theory in explaining the common law's notion of private property, this Article views occupancy theory as an incomplete prelude to Locke's more elegant version of the social compact story. To the extent, however, that occupancy retains independent standing in property theory, it merely underscores the importance of the exclusive dominion theme of traditional property theories. A property regime founded primarily on rights established through possession or occupancy would be even less receptive to societal limits on individual property rights than the other traditional property conceptions described in this Article because occupancy theory does not presume that all property was owned in common in the original state. See id. at 1229-30. Accordingly, occupancy theory may conflict with sustainability in a more fundamental way than the blended version of traditional property theories portrayed in this Article.

82. See Rose, supra note 71, at 603-07 (tracing all of these elements in Blackstone). 
principles led Blackstone to highlight the exclusive dominion attribute that accounts for the strong common law commitment to private property as an individual right.

As Carol Rose has convincingly shown, however, neither Blackstone nor the common law of his time literally subscribed to the notion of property as one person's "sole and despotic dominion" In fact, private property of Blackstone's time existed only within a context of the superior rights of the sovereign and the correlative rights of neighboring property owners. The first of these, the right of the sovereign to promote and protect public order and welfare, transformed into the inherent police power of democratic government in the United States. ${ }^{85}$ The second, the law of private and public nuisance, ${ }^{86}$ continues today as the common law's primary and ever-evolving restraint on private property rights. Thus, at least as concerns the historical basis for U.S. law, the notion of absolute dominion over property as a matter of individual right, wholly unaffected by the rights of society and government, is a myth, or at least an acknowledged idealization useful primarily to contrast theory with reality. ${ }^{87}$ What we can safely conclude from reading Blackstone is this: when the members of the Constitutional Convention met, as well as when the people of the original states adopted their own constitutions, they were operating within a theoretical framework committed to a strong concept of private property ownership. $^{88}$

While Blackstone notoriously characterized the common law's dedication to private property as an individual right, he did not offer a comprehensive theory of property sufficient for the United States'

83. BLACKSTONE, supra note 80 .

84. See Rose, supra note 71, at 601-06.

85. Sheppard, supra note 78, at 997 (observing that "commentators in the early federal period described the concept of police powers in terms consonant with the English common-law tradition, essentially substituting the state as the sovereign").

86. See Daniel R. Coquillette, Mosses from an Old Manse: Another Look at Some Historic Property Cases About the Environment, 64 CORNELL L. REV. 761, 765-72 (1979) (describing the early common law roots of nuisance doctrine).

87. See Rose, supra note 71, at 603-04 ("it might be best to conclude that for Blackstone, the Exclusivity Axiom was in a sense a trope, a rhetorical figure describing an extreme or ideal type rather than reality").

88. JENNIFER NEDElSKy, PRIVATE PROPERTY AND THE LiMITS OF AMERICAN COnstitutionalism: THE MAdison FramewORK AND ITS LeGACY 1-3 (1990); Stanley N. Katz, Thomas Jefferson and the Right to Property in Revolutionary America, 19 J.L. \& ECON. 467, 467-70 (1976). Even if this devotion to private property was not universal during colonial times, it quickly prevailed after the American Revolution. See Elizabeth V. Mensch, The Colonial Origins of Liberal Property Rights, 31 BuFf. L. REV. 635, 733-35 (1982). 
constitutional process. ${ }^{89}$ That important component, which predated Blackstone's Commentaries, came from seventeenth and eighteenth century political philosophy. ${ }^{90}$ John Locke's political philosophy was especially influential at the moment of the country's birth. ${ }^{91}$ Locke's famous syllogism on property emanated from his conception of natural law and the metaphoric social compact that he used to justify private property. Locke gave voice to the classic liberalism of Western political philosophy:

Though the Earth, and all inferior Creatures be common to all Men, yet every Man has a Property in his own Person. This no Body has any Right to but himself. The Labour of his Body, and the Work of his Hands, we may say, are properly his. Whatsoever then he removes out of the State that Nature hath provided, and left it in, he hath mixed his Labour with, and joyned to it something that is his own, and thereby makes it his Property. It being by him removed from the common state Nature placed it in, it hath by this labour something annexed to it, that excludes the common right of other Men. ${ }^{92}$

Locke's explanation holds much appeal, if for no other reason than because it offers a moral defense for the human instinct to acquire and control assets that are necessary for survival or useful for comfort.

Locke profoundly affected Jefferson's concept of property, although Jefferson was less concerned with property theory than he was with the relationship between property holding and good citizenship in a republic. ${ }^{93}$ Jefferson thought that ownership and cultivation of land were essential marks of personal virtue, and he believed that the opportunity for widespread land ownership in America made republicanism possible. ${ }^{44}$ Jefferson, of course, modulated Locke's "Lives, Liberties,

89. See Rose, supra note 71 , at 603-06 (explaining how lightly Blackstone dealt with the justification for strong private property rights).

90. In addition to John Locke's theory of property, discussed in the text, the property notions of Bentham and Hegel are often cited as particularly important for understanding an American framework of property. See Abraham Bell \& Gideon Parchomovsky, A Theory of Property, 90 CORNELL L. REV. 531, 541-43 (2005).

91. See Katz, supra note 88 , at $468-70$.

92. LOCKE, supra note $75, \S 27$.

93. See Katz, supra note 88 , at $478-84$ (discussing Thomas Jefferson's views on property).

94. Id. at 483 . 
and Estates" 95 so that happiness replaced estates, ${ }^{96}$ but that in no way diluted the importance of private property in our national psyche.

It is possible, however, to place too much importance on the role that Lockean theory or any other natural rights or social compact reasoning plays in contemporary U.S. notions of property, and it is error to interpret any of these traditional perspectives to require unrestrained private property rights. ${ }^{97}$ Furthermore, it is unproductive to pretend that any natural law or instinctive version of traditional property theory has much residual force in modern society. Stripped entirely of its implicit utilitarianism, a traditional theory along Lockean lines lacks credibility. ${ }^{98}$ For that reason, an assessment of sustainability theory in light of U.S. concepts of property rights can logically ignore as fanciful any justification for property that stems primarily from the labor theory or from some similarly artificial reliance on a social compact rationale. These pristine property theories simply leave too many pressing questions unanswered. If, for example, the premise rests on each individual's natural claim to the labor of his or her own body, how could the same political philosophy that revered property also have tolerated slavery? What is the essential link between a person's natural claim to his or her person and labor, and a right to appropriate the natural resources in which a person invests labor? To what extent does adding labor to a natural resource justify the laborer's exclusive dominion in the face of scarcity? How much labor earns the laborer a perpetual claim over the resource or its product?

At a minimum, these highly instinctive theories must concede, as both Locke's account and the common law did, that an individual should not gain property by disregarding the natural rights of others. ${ }^{99}$ Indeed, Locke noted that his argument presumed both an abundance of natural resources and the equal opportunity of all persons to acquire property through labor, ${ }^{100}$ and he made at least a passing nod to the affects of

95. LOCKE, supra note $75, \S 123$. Locke reserved the word "property" to encompass all three components when he reasoned that a man in the state of nature would rationally join in society "for the mutual Preservation of their Lives, Liberties, and Estates, which I call by the general Name, Property." Id.

96. THE DECLARATION OF INDEPENDENCE para. 2 (U.S. 1776).

97. See infra notes 99-101 and accompanying text.

98. See Bell \& Parchomovsky, supra note 90, at 603-04 (critiquing Lockean theory through modern references to eminent domain).

99. See Rose, supra note 71, at 603-04 (using Blackstone to assert common law beliefs regarding property).

100. Locke concluded his famous statement of the labor theory of property with this sentence: "For this Labour being the unquestionable Property of the Labourer, no Man but he can have a right to what that is once joyned to, at least where there is enough, and as good left in common for 
property ownership on the competing rights of others in society. ${ }^{101}$ Although the laborer logically may earn a property claim by adding value to a natural resource, that does not justify even an idealized notion of absolute, perpetual ownership in the natural asset itself. ${ }^{102}$

In fact, from its inception, the nation's property regime was considerably more practical than Locke's labor theory or any other intuitive philosophy of law. While natural rights concepts and Locke's labor theory continued to play important roles in justifying the social institution of property, they were not at the heart of the Federalists' devotion to property rights. ${ }^{103}$ The Federalists' idea of government, which ultimately prevailed over Jeffersonian republicanism, reflected a different, yet even stronger, commitment to property rights. ${ }^{104}$ In the Federalists' hands, property theory had more pragmatic, utilitarian, and political flavors that emphasized the need for a democratic society to protect private property from the oppression of majority rule. ${ }^{105}$ The Federalists insisted that strong property rights were essential to liberty and security in a democracy. ${ }^{106}$ This version of the traditional perspective incorporated the rudimentary utilitarian strains that were already evident in Blackstone ${ }^{107}$ and that were expressed more fully by leading political philosophers of the day, especially Jeremy Bentham. ${ }^{108}$ It also included some elements of "Hume's claim that the law of property is, at root, a convention that has evolved spontaneously-that 'arises gradually, and acquires force by a slow progression, and by our repeated experience." "'109

others." LOCKE, supra note 75, § 27 (emphasis added).

101. Id. §36. Locke, however, was more concerned about the basis for property rights than the potential limits on the use of property. See id.

102. Why, for example, many years after planting and cultivating a field and consuming the grain produced, should the laborer still have the right to exclude others from that field or to insist on heirs' rights to continue cultivating it for as long as they may wish? Does the woodworker earn the whole tree by carving a bowl from a branch? To the contrary, do natural property rights diminish as the human race expands and resources become increasingly scarce?

103. NEDELSKY, supra note 88 , at $28-30$.

104. See generally id. at $67-95$.

105. See id. at 3-9 (discussing property theory and the idea of limited government); Katz, supra note 88 , at $484-87$ (noting that protecting property rights was a principle function of the U.S. Constitution).

106. NedelsKy, supra note 88 , at 25-28. This American idea linking individual liberty to private property has persisted through the years. Ellickson, supra note 73, at 1352-54.

107. See Rose, supra note 71 , at 606-08 (showing evidence of utilitarian ideals within Blackstone).

108. Id. at 618-19.

109. Robert Sugden, The ECONOMics of Rights, Co-OPERATION AND Welfare 58 ( $2 \mathrm{~d}$ ed 2004) (quoting David Hume, A TReatise of Human NATURE 490 (L.A. Selby-Bigge ed., Oxford: Clarendon Press 1978) (1740)). 
From this more practical perspective, mere observation confirms that humans are instinctively acquisitive. The pragmatist concludes that government should establish those legal institutions, such as private property, that contribute significantly to human happiness. ${ }^{110}$ It does not matter so much whether this is important because God provided natural resources for human happiness, ${ }^{111}$ because instinct drives every individual to acquire property, ${ }^{112}$ or because human labor justifies the result. $^{113}$

On this basis, a version of classical utilitarianism, coexisting with natural law or intuition, emerged as the essential theoretical rationale for the U.S. political system's commitment to private property as being ineluctably linked to human happiness and civil order. ${ }^{114}$ Thus, long before the modern law and economics movement matured, a utilitarian perspective informed property theory in the United States without completely superseding the more instinctive arguments. ${ }^{115}$ For purposes of this Article, therefore, traditional theories of property are based, in different degrees, on natural rights, occupancy theory, Locke's labor theory, social compact reasoning, intuition, and classical utilitarianism. And, according to the inherited common law tradition, they are restrained by the antecedents of nuisance law and the power of government to protect the public order and welfare.

A property theory with that pedigree embraces strong individual property rights, but it also suggests that the law as applied must be practical. Individuals in society must accept limits on private property (and other individual rights) in exchange for the benefits that a wellordered political society offers. Over time, U.S. law engrafted many qualifications on the right of property. Some of these, such as those carrying on common law nuisance principles, were inevitable accommodations between competing property interests in a dynamic society that the courts worked out through the normal common law process. ${ }^{116}$ But others resulted only after considerable judicial anguish

110. Madison in particular reflected this view. See NEDELSKY, supra note 88, at 17

111. As already noted, much of Locke's theory reflected this view. See LOCKE, supra note 75.

112. See Ellickson, supra note 73, at 1353 (discussing relevant theories advanced by social scientists).

113. The Federalists" "ideas do not constitute political theory on the order of Locke...." NEDELSKY, supra note 88, at 13.

114. See Rose, supra note 71 , at 618-23.

115. See Katz, supra note 88, at 485-87 (discussing how such a balance was achieved).

116. See generally Guido Calabresi \& Douglas Melamed, Property Rules, Liability Rules, and Inalienability: One View of the Cathedral, 85 HARV. L. REV. 1089 (1972). 
because they tested the sanctity of property under the U.S. Constitution. ${ }^{117}$

The constitutional cases eventually spawned a process, reflective of the common law, by which courts balance property rights with other highly regarded civil rights and public policies. ${ }^{118}$ Because the balancing test approach breeds judicial discretion, scholars continue to debate both the legitimacy of the tests themselves and the application of those tests to particular cases. ${ }^{119}$ Reflecting a similar rationale, and also with a good deal of controversy, legislatures over the past several decades have modulated this common law theme by enacting land use and pollution control laws to strike a balance between private property rights and police power objectives. ${ }^{120}$ What is most important for our purposes is that, as presently understood, traditional property theories establish relatively few objective rules fixing the limits of governmental restrictions on property rights. As a result, appellate courts applying the traditional theories already have discretion to resolve conflicts between private property rights and the sustainability agenda by balancing the competing interests.

In this sense, traditional property theories may be reconciled readily with a conservationist theory of sustainability. The consistency arises because courts and legislatures in the United States, consistent with the common law tradition, necessarily have broad authority to impose limits on private property rights for the benefit of the constitutional society. On this basis, courts almost effortlessly developed the common law of riparian rights ${ }^{121}$ and contemporary applications of the common law rubrics of public and private nuisance. ${ }^{122}$ The underlying theme here is that, while private property rights are fundamental, for a democratic

117. See NeDELSKY, supra note 88, at 225-29 (discussing how the U.S. Supreme Court has treated property rights over the last century); MORTON J. HORWITZ, THE TRANSFORMATION OF AMERICAN LAW, 1780-1860, at 47-62 (1977) (discussing mill statutes which infringed on private property to promote economic development).

118. See, e.g., Penn Cent. Transp. Co. v. City of New York, 438 U.S. 104, 124 (1978).

119. See Circo, supra note 44, at 762-65 (discussing the debate between mandates and incentives in real estate development).

120. Id. at $745-46$

121. See, e.g., Lynda L. Butler, Allocating Consumptive Water Rights in a Riparian Jurisdiction: Defining the Relationship Between Public and Private Interests, 47 U. PITT. L. REV. 95, 105-07, 125-30 (1985) (discussing the reasonable use requirement); J. W. Looney, An Update on Arkansas Water Law: Is the Riparian Rights Doctrine Dead?, 43 ARK. L. REV. 573, 574-76 (1990) (“[E]ach riparian owner is entitled to make reasonable use ... of the water from a stream, but the right is extended only to that land which is considered to be riparian.").

122. See, e.g., J. H. Beuscher \& Jerry W. Morrison, Judicial Zoning through Recent Nuisance Cases, 1955 WIS. L. REV. 440, 440-42 (discussing trends in recent nuisance cases). 
society to thrive, the legal system must also recognize relatively significant limitations on private property.

We can also easily see the potential for conflict between traditional property theories and the generational and social justice theories of sustainability. Traditional property theorists do not inherently consider generational justice or social justice, although they may recognize that the justifications for private property rights depend on an abundance of natural resources within a specific society. ${ }^{123}$ In effect, because traditional property theories are temporally and geographically myopic, they simply may not perceive that subsequent generations, persons with marginal social status, or remote citizens of the earth have any competing claims that should limit the rights of property owners within a specific society or community. ${ }^{124}$

As already noted, as early as Blackstone, the traditional theories included at least an implicit utilitarian strain. As the study of economics grew into a highly developed field of social science steeped in utilitarian logic, the link between the traditional theories and utilitarianism evolved into a coherent economic analysis of property as a social institution. As the next part explains, economics provided the science necessary to argue that private property is inherently utilitarian.

\section{B. Selected Themes from Economic Theories of Property}

Economics studies human behavior in the face of scarce resources. ${ }^{125}$ In that light, an economic perspective claims to match the real world better than the more intuitive approaches of seventeenth and eighteenth century political philosophy. Several key assumptions about human behavior characterize neoclassical economic theory. ${ }^{126}$ First, an economic analysis of law assumes that people are rational decisionmakers and that they can predict and evaluate the probable consequences

123. See supra notes $99-101$ and accompanying text.

124. For a more complete evaluation of sustainability in light of traditional theories, see discussion infra Part V.A.

125. See Daniel H. Cole \& Peter Z. Grossman, Principles of LaW and Economics 1-2 (David Alexander \& Jeff Shelstad eds., 2005) ("[T] he economic problem is the necessity of choice under scarcity."); LIONEL ROBBINS, AN ESSAY ON THE NATURE AND SigNIFICANCE OF ECONOMIC SCIENCE 15 (1932) (concluding that economic science deals with "the forms assumed by human behaviour in disposing of scarce means"). For the most part, economic analysis in this Article relies primarily on the neoclassical economic perspective while recognizing that contemporary economic theory includes several distinct schools of thought.

126. There are, of course, competing applications of economic analysis to law. See COLE \& GROSSMAN, supra note 125, at 58-67. 
of available choices. ${ }^{127}$ In keeping with these fundamental principles of human behavior, an economic analysis further assumes that people will make logical choices to maximize self-interest - as defined by each person. ${ }^{128}$ Another key assumption is that governments should generally establish legal rules and institutions that efficiently maximize benefits to society as a whole. ${ }^{129}$ In the public realm, this means that the law should serve what economists generally call social welfare. ${ }^{130}$ Although these assumptions are important for purposes of the basic theoretical model, economists also recognize that these assumptions are imperfect and that they apply with a considerable degree of variation. ${ }^{131}$ Moreover, economists from different schools of thought have developed a variety of tools and approaches to conform economic analysis more closely to reality. ${ }^{132}$

These fundamental principles disclose that the economic perspective is essentially utilitarian. ${ }^{133}$ Given that traditional property theories also have strong utilitarian inclinations, ${ }^{134}$ what fundamentally distinguishes those theories from the contemporary economic perspective on property? The answer relates to the role that these contrasting theories assign to utilitarian objectives. While the traditional theories frequently incorporate utilitarian notions and apply them in an intuitive way, economics has a utilitarian soul that finds expression through scientific tools, objective analysis, and mathematical calculations. From the economic perspective, an individual's overriding goal, and therefore the motivation driving everyone's behavior, is to maximize his or her own interests, taking into account the person's subjective value system. ${ }^{135}$ Similarly, many economists argue that a society's overriding goal should be to realize the maximum utility for its citizens. ${ }^{136}$ For a legal system, a central proposition therefore emerges from these principles of economic analysis: Economically sound legal rules and institutions maximize social welfare at the least cost. An economic analysis, then, is a rigorous

127. See id. at 13-14 (explaining the concept of perfectly competitive markets); STEVEN SHAVELL, Foundations OF ECONOMIC ANALYSIS OF LAW 1-2 (2004) (introducing economic analysis of law).

128. COLE \& GROSSMAN, supra note 125 , at 5-8.

129. SHAVELL, supra note 127 , at 2-4, 597-98.

130. COLE \& GROSSMAN, supra note 125 , at 52 .

131. Id. at $18-20$.

132. See id. at 55-68 (discussing the history of law and economics).

133. See Bell \& Parchomovsky, supra note 90, at 543 (explaining Jeremy Bentham's utilitarian approach to law).

134. See supra notes $82,104-15$ and accompanying text.

135. COLE \& GROSSMAN, supra note 125 , at 3 .

136. SHAVELL, supra note 127, at 595-98. 
cost-benefit analysis. And an economically sound society and its institutions strive to maximize net social wealth within the context of a world constrained by limited resources and inhabited by rational interest maximizers.

How sustainability theory fares under an economic analysis of property, therefore, derives from the principle that a legal system should establish property rules that will operate efficiently to maximize social welfare. The concept of efficiency in economics is sophisticated and complex, and economists strive to quantify the analytical process. As a result, determining the extent to which an economic approach to the institution of property will accommodate the objectives of the sustainability movement requires a careful and thorough cost-benefit analysis.

Richard Posner explains an economic analysis of the legal institution of property in this way: "legal protection of property rights creates incentives to exploit resources efficiently."137 The economist's essential purpose is not to explain why this is true; it is sufficient to demonstrate by observation, experiment, and calculation that it is so. According to Posner, a property regime should leverage the overriding advantage of exclusive, individual ownership:

The proper incentives are created by parceling out mutually exclusive rights to the use of particular resources among the members of society. If every piece of land is owned by someone-if there is always someone who can exclude all others from access to any given areathen individuals will endeavor by cultivation or other improvements to maximize the value of land. Land is just an example. The principle applies to all valuable resources.

A simple situation involving two distinct property interests in a single parcel of land nicely illustrates Posner's economic analysis of property. Consider a landowner and a sharecropping tenant. The landowner provides the land and the tangible agricultural inputs, and the tenant contributes the labor. In Posner's example, the landowner and the tenant agree to divide the proceeds from the crops equally. He provides this economic analysis to show that the arrangement is not optimal:

Suppose that if the farmer worked an extra hour every week on improving the land he would increase the dollar value of the farm's

137. Richard A. Posner, ECONOMIC ANAlysis OF LAW 32 (Erwin Chemerinsky et al. eds., 6th ed. 2003).

138. Id. 
output by $\$ 2$ (net of any additional costs besides his time), and that the opportunity cost... of his time in forgone leisure is only $\$ 1.50$. Efficiency requires that he work the extra hour, but he will not, because under his deal with the landlord he will receive only $\$ 1$ for work that costs him $\$ 1.50$. $^{139}$

While the two parties could modify their sharecropping arrangement to create the appropriate incentive for the tenant to work the extra hour, that may involve costs to negotiate, monitor, and enforce the more complex agreement. Moreover, a truly efficient sharecropping agreement must address other problems that arise from divided ownership, such as providing incentives for one party or the other to invest in capital improvements that will optimize production. At least as far as Posner goes in exploring this illustration, it seems that an arrangement that puts one of the parties in sole title will inherently be more efficient than divided ownership. ${ }^{140}$

Note some important features of Posner's analysis of the sharecropping problem. His concern with how the arrangement divides the $\$ 2$ additional benefit between the landowner and the tenant is not whether the deal is fair, but whether it assures that the land produces the optimum value - the maximum net social welfare. From society's perspective, an economically sound arrangement should encourage the tenant to work the additional hour each week simply because that extra hour of work will exact $\$ 2$ of additional value in the aggregate in exchange for a total cost of only $\$ 1.50$.

In this respect, the economic perspective departs starkly from the traditional theories of property described in Part III.A, which tend to conceptualize property as a matter of individual rights. The economic analysis does not ask whether the arrangement contributes to the liberty or autonomy of either party; it simply posits that each party can reliably quantify the utility (benefits) and disutility (costs) involved and will act accordingly. The added crop value is the gross benefit to the social welfare. Because the total benefit involved (\$2) exceeds the total cost $(\$ 1.50)$, from a social welfare perspective the economically efficient outcome is clear: the tenant should work the extra hour, although the ownership structure dictates otherwise. The additional production would confer a known monetary benefit on the landlord at no additional cost, which means that the landlord favors the extra work, but, unless the landlord proactively decides to propose an adjustment to the sharing

139. Id. at 72 .

140. Id. at $72-75$. 
formula, the landlord will play no role in the decision. The additional production would also confer a similar monetary benefit on the tenant, who can also quantify the cost of the additional labor involved. On that basis, the tenant will choose the course that is less efficient for society because that course is more efficient for the tenant. In this case, the socially efficient result is to modify the sharecropping arrangement in some way that induces the tenant, as an economically rational actor, to work an extra hour per week.

Sustainability problems, of course, are considerably more complex than this stylized sharecropper situation, which only considers the interests and behavior of two stakeholders in relationship to an isolated decision. Sustainability involves the broadest and most long-term social effects of a property system on the behavior of many persons over space and time. The economic analysis, therefore, must expand.

The work of A. C. Pigou provides a logical place to begin exploring an economic analysis of property within a broader social welfare context. $^{141}$ It was he who made the concept of externalities a staple term in the economist's lexicon. ${ }^{142}$ An externality is an effect (either a burden or a benefit) of an activity that affects the behavior of a party other than the actor. ${ }^{143}$ A burden or cost created by the action or decision of one person or enterprise that is borne by others is a negative externality. Economic theory traditionally holds that an actor will not take into account the external effects of a contemplated action. In general, Pigou believed that externalities indicated market failures, and he argued that a main function of government should be to introduce and manage adjustments to cause externalities to be internalized into the relevant decision-making process. Pigou especially advocated the use of taxes to offset negative externalities. ${ }^{144}$ His analysis, however, may also be used to justify government subsidies and regulations calculated to influence economic decisions in circumstances in which natural market forces are inadequate to assure that the externalities of an economic decision properly figure into the cost-benefit analysis. ${ }^{145}$

Harold Demsetz's seminal development of an economic perspective on property rights and society applies Pigou's approach to externalities in

141. See generally A.C. Pigou, The EConomics of Welfare 24-30, 183-203 (4th ed. 1950); A.C. PigOU, Wealth AND Welfare 164-65 (1912).

142. See SHAVELL, supra note 127, at 108 ("The subject of externalities ... may properly be said to have originated with Pigou....").

143. Id. at 79 .

144. Id. at 108 .

145. See id. 
a way that is accessible even to those with limited knowledge of economics. ${ }^{146}$ Demsetz confirms the essentially utilitarian character of the economic analysis of property in this way: "Property rights are an instrument of society and derive their significance from the fact that they help a man form those expectations which he can reasonably hold in his dealings with others." 147 The right of property includes "the right to benefit or harm oneself or others," "148 an observation that "leads easily to the close relationship between property rights and externalities." ${ }^{149}$ In other words, to whatever extent a property system confers on an owner the freedom to choose how to use the property, an owner acting out of self-interest may choose to use the property in a way that imposes costs (harm) on others. Recall Posner's claim that an economically sound property system involves "parceling out mutually exclusive rights to the use of particular resources among the members of society." 150 To the extent that is true, an economically sound property system (one that promotes maximum social utility) must consider the costs to others that result from a property owner's decisions about how to use the property.

In a passage that seems to recognize the potential ecological limits of economics, Demsetz acknowledges that no effects of human conduct are "external to the world. ... What converts a harmful or beneficial effect into an externality is that the cost of bringing the effect to bear on the decisions of one or more of the interacting persons is too high to make it worthwhile" 151 for the property system to take into account. That is, as a matter of efficiency, the property system does not cause the person whose conduct produces the particular harmful or beneficial effect to feel the impact personally, and therefore the person logically does not include that effect in a cost-benefit analysis. When, by contrast, the property regime judges it economical to take beneficial or harmful effects into account, it internalizes those effects by "a process, usually a change in property rights, that enables these effects to bear (in greater degree) on all interacting persons." 152 Viewed from this perspective, "[a] primary function of property rights is that of guiding incentives to achieve a greater internalization of externalities." 153

146. See generally Harold Demsetz, Toward a Theory of Property Rights, 57 Am. ECON. ReV. 347 (1967) (discussing the close relationship between property rights and externalities).

147. Id

148. Id.

149. Id.

150. POSNER, supra note 137 , at 32 .

151. Demsetz, supra note 146, at 348.

152. Id.

153. Id. 
Recognizing the problem of externalities underscores an important challenge for a private property rights system, and sustainability considerations amplify that challenge. While economic analysis favors private property rights for the efficiency advantages Posner notes, a property regime also must be open to adjusting private property rights to compensate for externalities. Rather than insist on a doctrinaire commitment to private property rights, Demsetz emphasized that any system of property must behave according to economic principles, which in turn control the evolution of private property rights in society. $\mathrm{He}$ explained that a proper interpretation of his thesis "requires that account be taken of a community's preferences for private ownership. Some communities will have less well-developed private ownership systems and more highly developed state ownership systems." 154 Whatever the property regime, however, he argued that basic economic considerations dictate that "the emergence of new private or state-owned property rights will be in response to changes in technology and relative prices." 155

Thus, an economic theory of property does not inevitably assert the absolute efficiency or superiority of private property. ${ }^{156}$ In fact, in a much later piece, Demsetz concluded that "communal rights are the more efficient social arrangement under some circumstances." 157 Similarly, Robert Ellickson has shown that some forms of group ownership of land can be more efficient than individual ownership, especially within a close-knit group, for certain limited purposes, such as establishing the most efficient land boundaries for a particular land use ${ }^{158}$ or to spread risks efficiently in certain situations involving high-cost risks. ${ }^{159}$ But Ellickson's endorsement of communitarian property systems is highly qualified and limited to narrow circumstances. There is little in Ellickson's modest concessions to group ownership to contradict Demsetz's conclusion that "we know as a matter of fact that reliance on private ownership has increased on a trend basis over long stretches of time." ${ }^{160}$ At least when the calculus primarily reflects the costs and

154. Id. at 350 .

155. Id.

156. This conclusion may be reconciled with Posner's argument that exclusive ownership is the most efficient form because, as Posner makes clear, that is a general rule to which some exceptions apply. POSNER, supra note 137, at 34-37.

157. Harold Demsetz, Frischmann's View of "Toward a Theory of Property Rights", 4 REV. L. \& ECON. 127, 130 (2008).

158. Ellickson, supra note 73 , at 1332-35.

159. Id. at 1341-44.

160. Demsetz, supra note 157, at 131. 
benefits to those most immediately affected by an event, the efficiency thesis of economic analysis strongly favors private property.

How should an economically sound property system develop rules to address externalities? This is a critical question in the context of sustainability. Although Demsetz seemed to suggest that in the ideal economic system a property owner would bear all costs attributable to the owner's use of the property, ${ }^{161}$ that is not necessarily the case, especially when economic analysis focuses rigorously on net social welfare. In The Problem of Social Cost, Ronald Coase established his highly influential economic framework for analyzing externalities. ${ }^{162}$ In particular, Coase examined commercial activity that involves harm to those other than the owner of the property that generates the activity. $\mathrm{He}$ expressly considered two simple examples, among others: a factory that pollutes neighboring land, ${ }^{163}$ and a ranching operation from which straying cattle damage a neighboring farmer's crops. ${ }^{164}$ The resulting harm in each situation is a social cost. Coase challenged the prevailing economic analysis of the day, which he said would seek a device, such as damage liability or a tax, that would cause the factory or the rancher to internalize the harmful effects the activity imposes on others. ${ }^{165}$ Instead, he viewed the situation as involving reciprocal costs. If the factory, for example, is to have the right to operate for maximum productivity, the neighbors suffer harm in the form of the pollution, but if the neighbors are to have the right to enjoy their property free of the pollution, the factory suffers because it cannot operate at its optimum capacity. ${ }^{166}$ The issue, Coase argued, should not be which interest to protect but how best "to avoid the more serious harm." "67 This approach, therefore, requires the cost-benefit calculus to take into account the costs to the plant in lost production as well as the pollution costs to the neighbors.

Applying the analysis to the rancher's straying cattle, Coase demonstrated that if the standard assumptions of neoclassical economics apply, then no matter whether the legal rules require the rancher to pay for the harm the unruly cattle cause to the farmer's crops, or the farmer to pay the rancher to eliminate or reduce the crop damage, the rancher

161. See Demsetz, supra note 146, at 348.

162. See generally Ronald H. Coase, The Problem of Social Cost, 3 J.L. \& ECON. 1 (1960).

163. Id. at 1-2, 41-42.

164. Id. at $2-8$.

165. Id. at $1-2$.

166. Id. at 2 .

167. Id. 
will operate at the same optimal level. ${ }^{168}$ That is, so long as the parties have the practical ability to negotiate efficiently on their own-in economic terms, so long as there are no transaction costs and the parties have complete information - the parties will negotiate an agreement, such as payment by one party to the other, that redistributes the aggregate costs. The distribution will be to whatever extent, if any, necessary to permit the rancher to operate at a level at which the value the herd produces for the rancher exceeds all costs involved, including the costs that straying cattle impose on the farmer and any costs of mitigating the damage, such as fencing. While the legal rules will affect the relative wealth of the rancher in comparison to the wealth of the farmer by determining who will bear certain costs, it will not dissuade the rancher from building up the herd to the point that the total costs of operation, including all the costs of crop damage (whoever bears those costs), still allow incremental operations (increased herd size) to create excess net value. ${ }^{169}$ Under this analysis, economics seeks the optimal use of the land resources involved, which is a matter of aggregate social welfare, and it does not necessarily concern itself with equity between the neighboring landowners. The latter matter involves only the relative distribution of wealth between the competing interests rather than the efficient use of resources for the maximization of wealth in society.

But, of course, as Coase himself recognized, negotiating an economic solution to a property dispute invariably involves transaction costs, and most real life situations also involve other potential market failures, all of which may skew or even squelch negotiations. ${ }^{170}$ Under these circumstances, economic analysis supports a legal rule that "avoids the greater harm," such as a rule that imposes "the burden (or duty) of cost avoidance or abatement on the party that can do so at the lowest cost." 171 In practical terms, however, this may be a difficult goal to achieve, especially if the objective is to devise a legal rule that allocates the competing property rights in a way that avoids the dispute in the first place. For present purposes, however, the important point is that in a world in which there are always transaction costs and in which other economic assumptions apply imperfectly, an economic analysis should take into account all of the costs and should propose a rule that offers the best chance to achieve the maximum net social welfare.

168. Id. at $2-8$.

169. Id. at $7-8$.

170. Id. at $15-16$.

171. COLE \& GRossman, supra note 125 , at 87 . 
Notice the important difference between the economic approach as evidenced by Coase's straying cattle problem and a more traditional property law analysis. Traditional property theory might in fact become mired in the normative question whether to prefer the property rights of the rancher or the neighboring farmer. The usual solution would require either a preference rule (such as a first in time preference, or assigning a higher intrinsic value to one use or the other) or some kind of balancing of the competing rights that would seek to establish fair or reasonable correlative rights for the two property owners. ${ }^{172}$ This is, for example, roughly the approach we may find in nuisance law. ${ }^{173}$ But the ideal economic solution, once we recognize that there are reasons why the parties will probably not negotiate to the most efficient result on their own, would be to establish a pre-existing liability rule that has the greatest potential for maximizing the net social welfare. And, at least for many economists, there is no reason to be concerned about which of the two property owners must bear those costs that cannot be efficiently avoided. ${ }^{174}$

The discussion to this point reveals the centrality of net efficiency in economic analysis, which in turn exposes the normative aspects of the economic perspective. Those aspects involve at least two distinct value judgments. First, economic theory asserts that efficiency is a primary, and perhaps the controlling, purpose of a property system. This proposition implies a value judgment in the sense that not everyone recognizes the inherent virtue of efficiency, ${ }^{175}$ and even those who do need not concede that efficiency is the singular or the highest purpose of a property system. ${ }^{176}$ The economic preference for efficiency is rooted in

172. For example, the question of whether an invasion of a landowner's right to use or enjoy the land is a nuisance may be viewed as "a problem of relative values to be determined by the trier of fact in each case in the light of all the circumstances of that case." RESTATEMENT (SECOND) OF TORTS $\S 826 \mathrm{cmt}$. b (1977). Whether a balancing test this vague invokes an economic analysis depends on one's perspective. See Thomas W. Merrill, Global Warming as a Public Nuisance, 30 COLUM. J. ENVTL. L. 293, 328-32 (2005) (presenting various perspectives).

173. See, e.g., Carpenter v. Double R Cattle Co., 701 P.2d 222, 224 (Idaho 1985) (approving a jury instruction in a nuisance case that "consideration should be given to such factors as community interest, utility of conduct, business standards and practices, gravity of harm caused, and the circumstances surrounding the parties' movement to their locations").

174. In fact, many economic theorists posit that judges applying the common law of nuisance at times inherently seek an efficient result in a land use lawsuit between disputing neighbors. See, e.g., Calabresi \& Melamed, supra note 116, at 1115-24; Coase, supra note 162, at 19-28.

175. See Mark Sagoff, The Economy of the EARTh: Philosophy, LAW, AND ThE ENVIRONMENT (1988), as reprinted in REVESZ, supra note 18, at 21-31 (arguing against the use of efficiency to justify environmental and safety regulations that serve ethical and social purposes); SACHS, supra note 23, at 16-20 (declaring that the economic perspective is blind to realities not measured by a cost-benefit analysis).

176. See REVESZ, supra note 18, at 18-19 (introducing articles that do not value efficiency as the 
utilitarian values. The efficient use of assets is the use that produces consequences with the greatest net social utility. ${ }^{177}$ Note, however, that economic analysis does not determine which consequences have positive utility (benefits) and which involve disutility (costs), and that it recognizes that costs and benefits may count even if they are difficult to quantify. ${ }^{178}$ That is, the efficiency thesis values net social welfare, but it does not dictate how society defines welfare. Moreover, many economic theorists recognize that efficiency as measured by net social wealth is not the sole value that a property regime should serve. ${ }^{179}$ At the least, however, this initial ethical judgment of economic analysis is that, because efficiency is an inherent and important value, policymakers and judges should ask what rule or result will yield the greatest net social utility.

The second normative aspect of efficiency involves the practical meaning of efficiency for purposes of a cost-benefit analysis. Economists have developed important technical distinctions about how to judge efficiency for different purposes. ${ }^{180}$ Allocative efficiency, which "relates to the distribution of goods and services in an economy to maximize social welfare," 181 is especially important to consider in property disputes. As a practical matter, by promoting a cost-benefit analysis, the prevailing economic theory recognizes that certain allocations or reallocations of resources may be efficient if they result in a net gain in social welfare even if some persons are made worse off in the process. ${ }^{182}$ While theoretical debates continue over the meaning of efficiency for certain purposes, an economic analysis of law generally proceeds from this net cost-benefit approach in determining social welfare. ${ }^{183}$ But within this cost-benefit framework, competing economic theories disagree on the exact meaning of efficiency. ${ }^{184}$

However efficiency is defined, economic analysis also routinely asks whether the marketplace should be able to achieve the efficient result

\footnotetext{
highest purpose of an economic system).

177. COLE \& GROSSMAN, supra note 125 , at $12-13$.

178. POSNER, supra note 137 , at 11-12.

179. See id. at 10-16; Richard A. Epstein, How to Create-or Destroy-Wealth in Real Property, 58 ALA. L. REV. 741, 743 (2007) (discussing modern deviations from the common law).

180. For example, to an economist, efficiency may mean productive efficiency, allocative efficiency or adaptive efficiency. See COLE \& GROSSMAN, supra note 125, at 10.

181. Id. at 10-13.

182. See POSNER, supra note 137 , at $12-13$ (discussing wealth maximization).

183. Id. at 12 .

184. See, e.g., COLE \& GRossman, supra note 125, at 62-63 (discussing the contrasting views of the institutional law and economics school with those of the Chicago school).
} 
without governmental interference. ${ }^{185}$ As the economic literature adequately demonstrates, however, many complicating factors may impede market transactions. ${ }^{186}$ For example, if the costs of negotiation are too high, or if an agreement requires multiple parties to organize and collaborate, or if the parties do not have equal knowledge of the relevant economic factors, an optimizing transaction may never occur. Coase expressly recognized this problem when he wrote The Problem of Social Cost. ${ }^{187}$ For these reasons, even though neoclassical economic analysis commonly favors deference to the marketplace, economists acknowledge that market failures may require society to craft economic tools to create incentives for the sake of efficiency, and particularly with respect to environmental protection. ${ }^{188}$

Notice that the polluting factory problem ${ }^{189}$ involves several potentially critical market failures beyond the transaction costs that the feuding property owners must incur to negotiate a settlement. One especially disturbing prospect is that the factory may opt to produce at an inefficiently high level if the neighbors simply do not have the financial ability to pay the factory not to produce more pollution than the positive difference between the value of production and the cost of the pollution. ${ }^{190}$ But even if the neighboring landowners have the financial resources to pay the factory to limit the pollution, they will only pay whatever amount they calculate that a clean environment is worth to them. An environmentalist, therefore, must further object that the costbenefit analysis of this problem in the context of a private dispute is incomplete because it only accounts for the costs of the pollution by considering the damage that the neighboring property owners suffer, and then only to the extent that they can identify and evaluate that damage. ${ }^{191}$ What about other costs of the pollution, which may be far more widespread and difficult to discover or appraise than the immediate effects on the neighbors?

At this point, the relevance of the sustainability thesis begins to appear. For example, the pollution may increase cancer rates even

185. See POSNER, supra note 137 , at $383-85$ (comparing the common law rules to direct regulation)

186. Id. at 396-99.

187. Coase, supra note 162 , at $15-19$.

188. COLE \& GROSSMAN, supra note 125 , at $318-22$

189. See supra note 163 and accompanying text.

190. See POSNER, supra note 137, at 61 .

191. See Cole \& Grossman, supra note 125, at 317-18 (noting that not all of the effects of pollution are priced in markets and both these costs and any regulatory benefits may be difficult to quantify). 
among those who are unaware of the factory, including the unborn, or it may poison the water supply for an entire community much larger than the neighborhood, or we may only learn years later that the pollution helped to destroy a distant recreational area. To this, the sustainability advocate might add the even more substantial harm that the pollution may cause to remote future generations, especially when aggregated with countless other pollution sources across the globe and over the ages. For reasons such as these, an environmentally aware economist may still properly suggest that an economic tool, such as a Pigovian pollution tax, is appropriate to adjust for these market failures. ${ }^{192}$

Considerations of this kind do not defeat economic analysis; they merely demonstrate that the cost-benefit calculus may become extremely complex. To meet the challenge, economists have developed sophisticated methods and tools to value risks, quantify intangible benefits, adjust for irrational behavior, and even to determine a cost for future harms. ${ }^{193}$ With the help of these innovations, an economic perspective unquestionably provides a powerful set of tools for legal analysis. So much so that economic analysis dominates property theory in the United States. ${ }^{194}$ But to maintain that dominance, economic theorists must constantly parry their critics' thrusts. Any overview of the economic analysis of property in the context of sustainability, therefore, must consider some of the most relevant criticisms and the responses they evoke from the proponents of an economic analysis.

At a most fundamental level, critics sometimes object that an economic analysis fails to explain why efficiency should be a core value of a property system. ${ }^{195}$ From an environmental protection perspective, this criticism asserts that an economic analysis of property indefensibly presumes the value of exploiting resources to the fullest extent. ${ }^{196}$ One answer to this attack is that it is human behavior and not the economic perspective that determines the controlling value of efficiency. As Demsetz explained recently, while economic analysis presumes that people recognize the value of efficiency, that presumption does not necessarily promote a value judgment about efficiency simply because it deduces from observed human behavior "that people respond sensibly to

192. See Circo, supra note 44, at 762-65.

193. See POSNER, supra note 137, at 396-99.

194. See generally Bell \& Parchomovsky, supra note 90, at 551-66; Rose, supra note 71, at 618-23.

195. See COLE \& Grossman, supra note 125 , at 51 .

196. See generally Steven Kelman, Cost-Benefit Analysis: An Ethical Critique, REGULATION, Jan./Feb. 1981, as reprinted in REVESZ, supra note 18, at 93-98. 
a benefit-cost calculus." 197 In this sense, economic analysis is valid because it provides the most powerful analytic framework available for predicting what results legal rules will produce, and it suggests how to devise legal rules that more efficiently achieve the results that people will inevitably pursue. To the economist, the observation that efficiency is good is tautological because economics defines efficiency as the course of action that maximizes what human behavior recognizes as good.

A related objection is that economic theory actually advances questionable values $^{198}$ or that it camouflages them as objective, quantifiable costs and benefits. ${ }^{199}$ In response, the economic theorist may argue that at both the individual and the collective level, people decide which effects count as costs and which count as benefits, as well as what weight to assign to any particular effect. ${ }^{200}$ That is, because people define what they value and they act rationally in pursuit of those values, economics cannot assign value, although it can predict how social institutions can maximize what people perceive as value.

Other important criticisms are less theoretical and more practical. For example, even if economic analysis is fundamentally sound, it may be of limited use because the world is far more complex than the theory can manage. ${ }^{201}$ Economic assumptions are especially susceptible to this criticism. We know, for example, that transaction costs are often significant, that people rarely have all of the information they need to make rational decisions, and that people, including policymakers, regularly fail to act completely rationally. ${ }^{202}$ What is even more troublesome is that people often misjudge their own best interests and miscalculate or cannot quantify the most important costs and benefits a situation presents. ${ }^{203}$ In the real world, therefore, flawed or inadequately informed economic analysis may yield inefficient property rules in the same measure that sound economic analysis should produce efficient ones. $^{204}$ Proponents of economic theory, however, rejoin that even with

197. Demsetz, supra note 157 , at 128 .

198. See, e.g., Thomas W. Merrill, Explaining Market Mechanisms, 2000 U. ILL. L. REV. 275, 277 (noting that "command-and-control defenders argue that market mechanisms send the wrong message" because they "treat pollution as just another cost of doing business").

199. See Jabareen, supra note 22 , at $626-28$.

200. See Cole \& GROSSMAN, supra note 125 , at 51-52.

201. See generally Merrill, supra note 198, at 290-98 (analyzing why market mechanisms are used infrequently in environmental law and suggesting that a synthesis of wealth-maximization and distributional theories may provide an answer).

202. See COLE \& GROSSMAN, supra note 125 , at 79 .

203. See id. at $65-67$.

204. Michael Heller's influential work makes this point even as it advances the cause of 
all its flaws, economic analysis offers the best theoretical framework and tools for determining the most effective property system that humans can currently devise. ${ }^{205}$ Moreover, because economists recognize the limits of their science, they continually work to improve the available economic tools. ${ }^{206}$

In relation to sustainability, perhaps the most penetrating criticism of economic analysis may be that it fails to examine and resolve some key normative questions that should inform a property regime. ${ }^{207}$ From this perspective, a property system should do more than understand, reflect, or predict human behavior; it should regulate human behavior to achieve the proper goals of a virtuous society. Sustainability theory argues that those who own property today must recognize and respect the rights of future inhabitants of the earth not because that is the efficient course of action, but because it is moral in some entirely different sense. ${ }^{208}$ In contrast, economic discourse sometimes demonstrates a remarkable disassociation from ethical questions extraneous to an objective costbenefit analysis. For example, economic analysis may, with apparent dispassion, entertain the idea that a rational maximizer of self-interest may find satisfaction in, and therefore may assign value to, the misery of another person, ${ }^{209}$ or may be willing to pay a price to discriminate against other human beings on the basis of race, religion, or ethnicity. ${ }^{210}$ In this same vein, an economic analysis can provide an argument that it is rational for those who currently control natural capital to value their own

economic analysis. See Michael A. Heller, The Tragedy of the Anticommons: Property in the Transition from Marx to Markets, 111 HARV. L. REV. 621, 624 (1998) (explaining how "[1]egal and economic scholars have mostly overlooked" the problem Heller famously identified as the "anticommons"). The anticommons situation-in which excessive fragmentation of exclusive property rights causes underuse of a resource - may arise in a wide range of property arrangements. See generally Michael Heller \& Rick Hills, Land Assembly Districts, 121 HARV. L. REV. 1465 (2008) (discussing the use of eminent domain in economic development); Michael A. Heller, The UNE Anticommons: Why the 1996 Telecom Reforms Blocked Innovation and Investment, 22 YALE J. ON REG. 275 (2005) (discussing fragmentation of property rights caused by FCC requirements forcing companies to unbundle network elements); Michael A. Heller \& Rebecca S. Eisenberg, Can Patents Deter Innovation? The Anticommons in Biomedical Research, SCIENCE, May 1, 1998, at 698 (discussing the need to more carefully deploy patents and other intellectual property protections in the field of biomedical research in order to ensure "upstream research and downstream product development").

205. See generally POSNER, supra note 137, at 17-18 (discussing unrealistic assumptions underlying economic theory and why those assumptions are necessary).

206. See COLE \& GROSSMAN, supra note 125, at 58-67 (discussing the evolution of economic analysis of the law).

207. See, e.g., Singer, supra note 73, at 328-38 (proposing a citizenship model to answer some of the questions that economic analysis does not).

208. Engel, supra note 14, at 2-5.

209. POSNER, supra note 137 , at 3.

210. Id. at 681 
current consumption over the preferences of those remote in relationship, place, and time. This merely shows that efficiency may be conceptually distinguished from a society's ethics; it does not mean that the two are necessarily incompatible. ${ }^{21}$

What are the potential theoretical conflicts between sustainability and the economic analysis of property? While it is relatively easy to correlate sustainability with traditional theories of property, the task is far more difficult when we substitute the economic perspective. This difficulty stems both from the complexity of economic analysis and from the need to develop a common language for exploring whether and under what circumstances the use of natural resources may be optimal in both the economic and the sustainable sense.

There is, however, no inherent conflict between the goals of sustainability and economic efficiency. While economic theory is concerned with the most efficient exploitation of natural resources, economics need not dictate how to quantify the costs and benefits that flow from a particular use of resources. Posner illustrates this point when he observes that a cost-benefit analysis "merely compels the decision maker to confront the costs of a proposed course of action." 212 In this sense, economic analysis serves its purpose simply by testing whether the benefits justify the associated costs. "If the government and the taxpayer and the voter all know - thanks to cost-benefit analysisthat a project under consideration will save 16 sea otters at a cost of $\$ 1$ million apiece, and the government goes ahead, there is no basis in economic theory for criticism." 213 This suggests the important conclusion that if decision-makers place a sufficiently high value on sustainability, economic theory will recognize that choices in favor of sustainability may be efficient even if they involve extremely high costs. $^{214}$

\section{Selected Themes from Alternative Theories of Property}

This part considers selected contemporary perspectives on property that are not dominated by economic analysis and that seem especially relevant to the sustainable development movement. The common thread

211. See id. at 683-84 (comparing the relative efficiency of alternative remedies for victims of illegal racial segregation in public schools).

212. Id. at 397 (footnote omitted).

213. Id.

214. For a more complete evaluation of sustainability in light of economic analysis, see discussion infra Part V.B. 
of the alternative theories examined in this part is that they define property rights within a context of interdependent social relationships, and it is this distinction that makes these theories especially useful for analyzing potential conflicts between private property and sustainability. For convenience, the discussion that follows refers to these perspectives as relational theories of property. ${ }^{215}$

The most distinctively relational approaches can be nearly dogmatic in rejecting the deference to private property rights that characterizes the traditional and the economic theories. But a property theory may incorporate relational concepts without becoming radical and without rejecting traditional and economic perspectives. Carol Rose, for example, reflects a more inclusive vision in her especially coherent characterization of property as a dynamic institution responsive both to individual rights and to social relationships. She offers the following synthesis, which can accommodate traditional, economic, and relational concepts: "Property regimes always consist of some individual rights, mixed with some rights shared with nearby associates or neighbors, mixed with still more rights shared with a larger community, all held in relatively stable but nevertheless changing and subtly renegotiated relationships." 216 Rose's eclectic approach provides a good starting point from which to consider relational theories.

A critical feature of the relational theories most relevant to sustainability is that, at least in certain circumstances, they raise serious doubts about the justifications for strong private property rights. Indeed, some relational writers protest that traditional and economic theorists are more interested in protecting private property rights than in justifying them. ${ }^{217}$ Traditional property theories, for example, assert that natural law, intuition, or quasi-scientific logic provides a sufficient basis for private property rights. ${ }^{218}$ These arguments, as Rose demonstrates, amount to little more than defending private property with a "just-so story." 219 Because traditionalists tend to see private property as a natural consequence of the human condition, if not as a natural right, they are more interested in articulating an acceptable explanation for the status quo than in engaging in a genuine debate over the just allocation of

215. See Bell \& Parchomovsky, supra note 90, at 550-51 (referring to a perspective on property "emphasizing the interpersonal relationships surrounding property rights," and naming Margaret Radin's work as a prime example of a relational approach).

216. Rose, supra note 71, at 631.

217. See id. at 623-30.

218. See Rose, supra note 74, at 330-33.

219. Rose, supra note 71 , at 606-09, 618-19. 
resources. Proponents of economic analysis arguably expend even less energy on the justification question because economic theory stems from a utilitarian morality that requires no greater justification for private property rights than the evidence that private property tends to maximize aggregate wealth in society. ${ }^{220}$ In this sense, the economic perspective aspires to be more scientific or observational than philosophical or normative.

In contrast to both the traditional and the economic approaches, a relational perspective often shines an especially intense spotlight on the justification question. A general theme that emerges via these relational theories is that, in a world of interdependent relationships, a property regime should serve some central ethical values beyond rationalizing the status quo or maximizing wealth. The relational theories discussed here often place social justice at the heart of their analyses, and several reflect the critical legal theorist's advocacy of "an outsider's stance" 221 and a "commitment to a more egalitarian society." 222

By viewing property in the context of interdependent relationships, relational theories seek a construct for the social institution of property that derives from a common understanding of social justice, especially distributive justice. ${ }^{223}$ One of the most influential and coherent modern expositions on justice is John Rawls's A Theory of Justice, ${ }^{224}$ which advances a notion that Rawls called "justice as fairness." 25 In his attempt to take Locke's social contract theory "to a higher level of abstraction," ${ }^{, 26}$ Rawls argued that the just social contract would be an agreement made among equals. ${ }^{227}$ His theory posited "the principles of justice for the basic structure of society ... that free and rational persons concerned to further their own interests would accept in an initial position of equality ....,228 According to Rawls, to know justice as fairness:

220. See id. at $618-23$.

221. Roy L. Brooks, Structures of Judicial Decision-MaKing From Legal Formalism TO CRITICAL THEORY 193 (2002).

222. James Boyle, CritiCal Legal Studies xiv (James Boyle ed., 1992). The best example is Joseph Singer's argument that workers should have property rights in a plant their employer proposes to close. See infra notes 249-53 and accompanying text.

223. See Singer, supra note 73, at 331-32.

224. John RAWLS, A THEORY OF Justice (Rev. ed. 1999).

225. Id. at 3 .

226. Id.

227. Id. at 10 .

228. Id. 
[W]e are to imagine that those who engage in social cooperation choose together, in one joint act, the principles which are to assign basic rights and duties and to determine the division of social benefits. Men are to decide in advance how they are to regulate their claims against one another and what is to be the foundation charter of their society. Just as each person must decide by rational reflection what constitutes his good, that is, the system of ends which it is rational for him to pursue, so a group of persons must decide once and for all what is to count among them as just and unjust. The choice which rational men would make in this hypothetical situation of equal liberty ... determines the principles of justice. ${ }^{229}$

The Rawlsian theory of justice as fairness is especially relevant to the institutions of a just society, one of which is the institution of property. These "principles are meant to answer the question: once we view a democratic society as a fair system of social cooperation between citizens regarded as free and equal, what principles are most appropriate to it?" ${ }^{230}$ Rawls was deeply interested in the question of inequity, and his concept of a "property-owning democracy" incorporates safeguards against the excessive concentration of property and wealth. ${ }^{231}$ His just savings principle anticipates significant constraints on private property to achieve generational justice. ${ }^{232}$ Consequently, justice as fairness treats property and wealth in ways that contrast sharply with both utilitarianism and capitalism. ${ }^{233}$ But it would go too far to say that Rawls's social contract theory promoted a relational theory of property. His focus was not on interdependent relationships but on how individuals acting freely in their own best interests would settle on the principles of justice for their society. Moreover, his principles of justice offered only tentative details about the institutions of a just society, and they did not attempt to develop a comprehensive property theory at all. ${ }^{234}$

What is most important for purposes of this Article is that Rawlsian principles of justice contemplate a society designed to maintain a just structure throughout all generations. In considering whether social systems are just, Rawls called for intergenerational justice as well as justice among those living in society during a single era. ${ }^{235}$ He gave

229. Id. at $10-11$

230. John RAWLS, JusticE AS FAIRNESS: A RESTATEMENT 39 (Erin Kelly ed., 2001).

231. Id. at 135-40. The theory did not, however, state a preference between a "property-owning democracy and a liberal socialist regime." Id. at 139.

232. See id. at 158-61 (discussing the just savings principle).

233. See RAWLS, supra note 224 , at $12-14,50-52$.

234. See RAWLS, supra note 230, at 135-36.

235. RAWLS, supra note 224, at 251-62; RAWLS, supra note 230, at 158-61. 
central importance to the question of distributive justice across generations, which he stated in this way: "how are the institutions of the basic structure to be regulated as one unified scheme of institutions so that a fair, efficient, and productive system of social cooperation can be maintained over time, from one generation to the next?"236 He reasoned that because "society is to be a fair system of cooperation between generations over time, a principle governing savings is required." ${ }^{237}$ This emphasis on justice for all generations of a society creates a framework for thinking of sustainability as an element of justice, an idea that finds expression in Rawls's just savings principle. For Rawls, the principle of just savings meant that social institutions should "make possible the conditions needed to establish and to preserve a just basic structure over time. $" 238$

The Rawlsian principles of justice do not, however, expressly consider how humans should behave toward nature, ${ }^{239}$ and they do not coordinate directly with contemporary sustainability theory. ${ }^{240}$ Because the just savings principle does not deal explicitly with the natural environment, justice as fairness does not sound the ecological theme that is central to the sustainability movement. Also, Rawls's principles of justice do not reflect the global perspective of a sustainability theory.

In considering intergenerational justice and the principle of just savings, Rawls was more concerned with social institutions and capital formation within a single political society than with global natural resources. He reasoned that "[e]ach generation must not only preserve the gains of culture and civilization, and maintain intact those just institutions that have been established, but it must also put aside in each period of time a suitable amount of real capital accumulation."241 For Rawls, just savings might "take various forms from net investment in machinery and other means of production to investment in learning and education." ${ }^{242}$ In developing his just savings principle, therefore, Rawls did not have in mind the concept of natural capital as known to the sustainability movement. From his somewhat narrower perspective, Rawls held open the possibility that at some point accumulated

\footnotetext{
236. RAWLS, supra note 230 , at 50.

237. Id. at 160 .

238. RAWLS, supra note 230, at 159.

239. RAWLS, supra note 224, at 15.

240. For an attempt to extrapolate from Rawls to sustainability theory, see Oluf Langhelle, Sustainable Development and Social Justice: Expanding the Rawlsian Framework of Global Justice, 9 ENVTL.VALUES 295, 300-07 (2000).

241. RAWLS, supra note 224 , at 252 .

242. Id.
} 
intergenerational savings might fully satisfy the conditions necessary for ongoing just social institutions, at which time "net real saving may fall to zero." "243 If advocates of sustainable development are right, no society can ever achieve those conditions simply by investing in cultural assets and the means of production.

But even with these limitations in mind, the Rawlsian principles of justice not only anticipate the need for sustainability in the institutions of a just society, but they also are compatible with a relational theory of property. In particular, Rawls's argument for a just savings principle points toward a theory of sustainability based on generational justice, and his analysis of distributive justice is receptive to relational concepts of property. Thus, while the Rawlsian concept of justice did not itself directly propose environmental sustainability, nor did it advance a relational theory of property, its just savings principle, together with its notions of social cooperation and distributive justice, helped to create a framework for advancing sustainability as an element of justice within relational property theories.

What is especially significant for present purposes is that a Rawlsian concept of justice informs some explicitly relational property theories that are particularly relevant to sustainability. Joseph Singer provides an apt example when he contrasts what he calls the citizenship model of property with the castle model (a traditional perspective of property as private dominion over particular resources) and the investment model (a utilitarian or economic perspective). ${ }^{244}$ What distinguishes Singer's citizenship model is that it "starts from the idea that owners have obligations as well as rights." "245 Given this premise, Singer's analysis of property quickly leads to an inquiry about fairness and justice in the context of interdependent relationships:

Part of what it means to be a member of society, to be an owner among owners, is to be part of a real or imagined social contract that limits liberty to enlarge liberty, that limits property to secure property. This does not mean that obligations are justified merely because they are demanded by society; it does mean that the central question is whether the obligation is fair or just. ${ }^{246}$

Drawing on the Rawlsian concept of justice as fairness, Singer argues "that owners are legitimately subject to just obligations and that such

243. RAWLS, supra note 230, at 159.

244. See Singer, supra note 73, at 313-14.

245. Id. at 314 .

246. Id. at 329 . 
obligations are in no way incompatible with the concept of ownership. The only question is whether a law limiting the rights of the owner is a just obligation." ${ }^{247}$ This approach leads to a relational inquiry about distributive justice. "[T] he crucial question is not just the rights of the individual owner vis-à-vis the state but the right relationships that must be established between the owner and others in the community." 248 Assuming a global or intergenerational definition of the relevant community, the argument for adapting property theory to sustainability is obvious.

In another application of this relationship approach to property rights, Singer argued that relationships can even create property rights in much the same way that relationships can create contract rights or give rise to tort liability. ${ }^{249}$ Using this perspective, Singer argued that a company's employees and the community in which the company operated a manufacturing plant could have a sufficient relationship with the plant to give rise to property rights in the face of the company's plans to close the plant. ${ }^{250} \mathrm{He}$ concluded "that we should understand property as social relations, rather than through the lens of the free market model." ${ }^{251}$ This approach places an openly ethical gloss on property used for commercial purposes by stressing the interdependence of a business enterprise and those it affects. "The social relations approach asks us to be sensitive to the power inequalities within those relationships .... We should focus on the various ways in which vulnerable persons rely on relationships of mutual dependence. This perspective will give us a deeper understanding of how the legal system regulates economic life." 252 More recently, Professor Singer has argued that any legal right, and particularly a property right, "should be understood not merely by reference to the powers and rights it gives the owner but by reference to the impacts of the exercise of those powers on others and the shape and character of the social relationships engendered by those rights and powers." 253

In a similar vein, Jennifer Nedelsky insisted that "property really is a set of legal rules and norms that structure power and relationships....

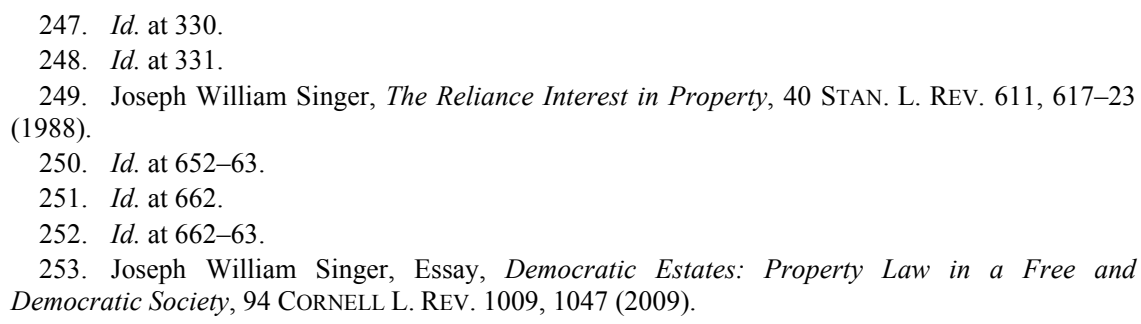


The rules of property tell us who has to ask whom for what, and how much power or powerlessness they will have in their request." 254 In her view, the traditional concept of property rights under the U.S. Constitution wrongly treated property as "the defining instance of the larger problem of securing justice and liberty in a republic." ${ }^{255}$ This elevated status of property rights produced a "lasting and destructive legacy"256 that was "inseparably tied to inequality." 257 She explained the errant thinking in this way:

The link to inequality was liberty. Property was important for the exercise of liberty, and liberty required the free exercise of property rights; this free exercise would inevitably lead in turn to an unequal distribution of property. Property thus posed a problem for popular government because this inequality required protection; those with property had to be protected from those who had less or none.... [I]t was in the very nature of a productive system of private property that many, perhaps most, would have none.

The core problem, Nedelsky concluded, was that this perspective "makes inequality rather than liberty, or individual autonomy, the central problem of government." 259 Nedelsky's alternative perspective was a radically instrumental vision:

We need to take our traditional concepts like property and ask what patterns of relationship among people and the material world we want, what patterns seem true to both integrity and integration. Those questions do not necessarily preclude a concept of property, but they imply a focus not on limits but on forms of interaction and responsibility for their consequences. ${ }^{260}$

From this same theoretical framework, Nedelsky argued:

[R]elationship, not separation makes autonomy possible. This recognition shifts the focus from protection against others to structuring relationships so that they foster autonomy.... Interdependence

\footnotetext{
254. Jennifer Nedelsky, Law, Boundaries, and the Bounded Self, RePreSENTATIONS, Spring 1990 , at 162,177

255. Id. at 164

256. Id.

257. Id.

258. Id

259. Id. at 165 .

260. Id. at 184 .
} 
becomes the central fact of political life.... The whole conception of the relation between the individual and the collective shifts: the collective is a source of autonomy as well as a threat to it. ${ }^{26}$

Some other contemporary property theories emphasize relationships between property and individuals rather than relationships within communities or society. A leading example is Margaret Radin's personhood theory of property. ${ }^{262}$ Drawing on Hegel's Philosophy of Right, ${ }^{263}$ Radin's analysis "focuses on personal embodiment or selfconstitution in terms of "things." 264 She explained that "[t]he premise underlying the personhood perspective is that to achieve proper selfdevelopment - to be a person - an individual needs some control over resources in the external environment. The necessary assurances of control take the form of property rights." 265 Radin argued that "the personhood perspective is often implicit in the connections that courts and commentators find between property and privacy or between property and liberty." 266

Thus, the personhood theory asserts that some measure of private property is essential as a matter of human rights. Social science research supports this notion by demonstrating that a person stripped of possessions instinctively seeks some control over objects or territory as a way of establishing his or her personal identity. ${ }^{267}$ Because the theory is closely connected to a sense of human dignity, it illustrates a strong judgment about the role of property in society. While Radin recognized that the personhood perspective does not necessarily offer a comprehensive theory of property rights, ${ }^{268}$ she argued that this understanding of property can "serve as an explicit source of values for making moral distinctions in property disputes, and hence for either justifying or criticizing current law."269

261. NEDELSKY, supra note 88 , at 273 .

262. See generally Margaret Jane Radin, Property and Personhood, 34 STAN. L. Rev. 957, 959 68 (1982).

263. Georg Hegel, Philosophy of Right (T. M. Knox trans., 1967). Radin discusses at some length the relationship between her personhood perspective and Hegel's property theory. See Radin, supra note 262 , at $971-78$.

264. Radin, supra note 262, at 958 .

265. Id. at 957 .

266. Id. (footnote omitted).

267. See ERving Goffman, Asylums: Essays on the Social Situation of Mental PATIENTS AND OTHER INMATES 307 (1961) (documenting that acquisitive behavior of patients in mental hospitals serves to establish individual identity in an anonymous environment).

268. Radin, supra note 262, at 1013-14.

269. Id. at 957. 
In developing this theory, Radin contrasted strong versus weak relationships between individuals and their possessions. A strong personal relationship with an object exists "if its loss causes pain that cannot be relieved by the object's replacement." ${ }^{270}$ A much weaker relationship exists with respect to "an object that is perfectly replaceable with other goods of equal market value."271 Based on this distinction, property to which a person has a strong personal attachment should receive greater legal protection than commercial property, which is essentially fungible. ${ }^{272}$ With respect to sustainability, the most significant implications of a property theory that emphasizes a continuum of property rights ranging from the highly personal to the completely fungible is that it might allow relatively greater deference to government regulation of privately owned property that falls toward the fungible or commercial end of the continuum. The personhood theory of property eventually led Radin to entertain radical arguments for wealth redistribution. ${ }^{273}$ In that sense, her theory would presumably tolerateand perhaps it would promote - a sustainability agenda based on social justice.

These few examples of alternative property theories indicate that relational perspectives should be receptive to limitations on property rights based on the most far-reaching sustainability objectives-much more so than are the traditional or the economic approaches. ${ }^{274}$ The next part illustrates that legislatures and courts in the United States operate comfortably within traditional and economic models, and it questions whether they are prepared to embrace the more relational concepts that the sustainability movement may require.

\section{EXPLORING THE LEGISLATIVE AND JUDICIAL BOUNDARIES OF PROPERTY RIGHTS AND SUSTAINABILITY}

Where sustainability and property interests intersect, the true test of the alternative theories discussed in Parts II and III will play out in the sustainable development initiatives that survive the legislative process and ultimately face judicial scrutiny. That is, the theoretical distinctions with the greatest practical significance will manifest themselves most

\footnotetext{
270. Id. at 959 .

271. Id. at 960

272. Id. at $987-88,1015$.

273. Id. at $988-91$.

274. For a more complete evaluation of sustainability in light of relational theories, see discussion infra Part V.C.
} 
clearly when government chooses one course of action over another on controversial matters affecting sustainability and private property rights. As the sustainability agenda begins to encroach more aggressively on private property rights, which theories will prevail in the nation's legislatures and courts? To modulate the analysis from an inquiry about abstract perspectives to an examination of concrete decisions, this part explores the theories of property and sustainability currently embodied in a few prominent statutes and court cases.

\section{A. The Legislative Context}

Environmental protection legislation that infringes on private property rights often gives rise to significant policy debates that highlight a legislative commitment to a particular property theory. ${ }^{275}$ Competition in the legislative arena most frequently takes place between traditional and economic perspectives on property. Consider, for example, a debate over legislation to protect endangered species, which may either focus on the justification for limiting a property owner's freedom to develop protected habitat $^{276}$ or may ask whether the legislative deliberations properly weighed the ecological benefits against the social costs involved. ${ }^{277}$ The justification question may primarily evidence a traditional perspective on property, while the second inquiry explicitly invokes economic analysis. In some situations, economic analysis dominates. A recent example dealing directly with sustainability is a Washington statute that authorizes public utility districts to mitigate the effects of their greenhouse gas emissions through the "purchase, trade, and banking of greenhouse gasses offsets or credits." "278 A better known example addressing more conventional environmental protection involves the well-documented debate over tradable permit programs, which use economic models and economic instruments to require

275. See ReVESZ, supra note 18, at 2-49. See also Palazzolo v. Rhode Island, 533 U.S. 606, 630-31 (2001) (rejecting a landowner's regulatory takings claim stemming from the Rhode Island Coastal Management Council's denial of a development application for a waterfront parcel because the record reflected that a portion of the property retained development value).

276. See Robert Meltz, Where the Wild Things Are: The Endangered Species Act and Private Property, 24 ENVTL. L. 369, 377-91 (1994) (observing that the habitat areas for listed endangered species often conflict with private land ownership).

277. See id. at 370 (stating that the ESA weighs "private economic activity against national concern for aesthetic, ecological, scientific, and recreational values"); Barton H. Thompson, The Endangered Species Act: A Case Study in Takings \& Incentives, 49 Stan. L. Rev. 305, 343-54 (1997) (explaining that compensation for private landowners has been expanded in recent years).

278. WASH. REV. CODE $\S 54.16 .390$ (2008). The statute effectively overrules the result in Okeson v. City of Seattle, 150 P.3d 556 (2007), discussed at length infra in Part IV.B.2. 
industries to internalize the social costs of their polluting activities to achieve economic efficiency. ${ }^{279}$ On environmental issues involving less quantifiable costs and benefits, however, legislative policies sometimes reflect the far more instinctive approach of traditional property theory, under which a rough balancing standard determines when property rights must yield to competing public welfare interests. This more traditional perspective presumably informed a legislative decision that directed the Environmental Protection Agency to establish air quality standards without undertaking a cost-benefit analysis. ${ }^{280}$

Current legislative initiatives from the sustainable development movement in the United States also invoke both traditional and economic theories of property. For example, municipalities sometimes base green building programs on a traditional land use control model that balances the rights of developers against the general public interest and the welfare of neighboring landowners; but, at other times they adopt economic tools directed at perceived market failures. ${ }^{281}$ For example, the growing support for green building codes reflects a traditional land use control approach. ${ }^{282}$ Yet, at the same time, and with even more widespread support, cities and counties across the country have been crafting economic incentive programs to encourage sustainable development. ${ }^{283}$

It is more difficult to find environmental initiatives in this country that distinctly reflect relational property theories, although the international sustainability movement frequently advocates relational

279. See Cole \& Grossman, supra note 125, at 332-40 (describing the method for mathematically calculating the proper amount of tradable credits to be allocated to a level of pollution); EBAN S. GOODSTEIN, ECONOMICS AND THE ENVIRONMENT 309-13 (3d ed. 2002) (explaining the use of incentive-based regulation via permits or taxation, which put a "price on pollution" to help deter corporations and individuals from polluting).

280. See Whitman v. Am. Trucking Ass'ns, 531 U.S. 457, 464-77 (2001) (detailing the use of economic models in determining realistic guidelines for emission reduction initiatives).

281. See generally Circo, supra note 44, at 751-65 (discussing alternative bases for several green building ordinances).

282. See Mayor Menino’s Green BuIlding TASK Force RePOrt, EXECutive Summary 9 (2004), available at http://www.bostongreenbuilding.org/ (follow "Click here to view the Executive Summary" hyperlink) (proposing that Boston adopt mandatory green building standards); Press Release, U.S. Green Bldg. Council, New Standard to Drive High Performance Bldg. Practices to the Mainstream (Feb. 15, 2006), available at http://communicate.usgbc.org/press/2006/02.15.06 _ashrae/standard189.html (establishing a new standard for high-performance green buildings); see generally U.S. GREEN BLDGS. COUNCIL, LEED INITIATIVES IN GOVERNMENTS AND SCHOOLS (2009), available at http://www.usgbc.org/ShowFile.aspx?DocumentID=691 (providing an extensive list of jurisdictions that have adopted green building programs, including several that have incorporated green building standards into their building codes).

283. See Circo, supra note 44, at 756-62 (discussing specific examples of enacted green building programs across the U.S.). 
perspectives. ${ }^{284}$ To be sure, relational notions influence some of the debates over the extent to which property owners have responsibilities toward future generations, but there is little evidence that governmental sustainability programs in this country will implement a relational perspective on property. ${ }^{285}$ Successful sustainability initiatives generally require the legislative body to conclude either that a proposed restriction imposes only a limited, reasonable infringement on the traditional ideal of exclusive property or that it is justified on a cost-benefit analysis. Indeed, as Part V of this Article concludes, there is little basis to expect that the relational theories most aligned with sustainability in the strong sense will significantly influence legislative policy debates in this country.

\section{B. The Judicial Context}

As the sustainability movement begets more extensive and vigorous legislative and regulatory action, courts must determine the circumstances under which sustainability considerations authorize the government to encroach on private property rights. What theoretical paths will courts explore when sustainability strategies threaten property rights? The balance of this part analyzes three recent cases that provide a roadmap. In the first two cases, the United States Supreme Court confirmed its allegiance to traditional property theories, tempered by a broad respect for legislative judgments on economic policy. In the third case, a divided Supreme Court of Washington paid homage to an ambitious sustainability initiative even while overturning the specific program on technical grounds. The contrasting opinions of the justices in the Washington case illustrate alternative judicial perspectives on sustainability as public policy. Thus, although none of the three cases discussed here pits property rights against sustainability, taken together, they outline the theoretical contours of a property rights clash with sustainability.

284. See HACKETT, supra note 3, at 323 (advocating sustainable development as socially responsible); King \& King, supra note 8, at 400-01 (2005) (arguing for sustainable development standards to achieve distributive justice).

285. See Beatley \& Collins, supra note 12, at 312 (explaining that a "profound shift towards sustainability" requires a complete re-thinking of the use and management of land as a form of natural capital). 


\section{Property Theory in the United States Supreme Court's Takings} Jurisprudence

One of the most recent and instructive property rights decisions from the United States Supreme Court is Lingle v. Chevron U.S.A. Inc., ${ }^{286}$ decided under the Takings Clause of the Fifth Amendment. ${ }^{287}$ While it would be a mistake to assume that the constitutional notion of property is exactly coterminous with property theory in the United States, Takings Clause cases teach much about prevailing property theories. Indeed, the scholarly debate over property theory in this country frequently takes place in the context of constitutional analysis. ${ }^{288}$ The Lingle case reviewed and clarified some of the most fundamental aspects of the Court's implicit property theory.

Chevron sought a declaratory judgment that Hawaii took Chevron's property by imposing a statutory cap on rent that Chevron and other oil companies could charge their lessee-dealers. ${ }^{289}$ Hawaii adopted the measure to protect independent dealers and retail consumers from the adverse effects of concentration in the wholesale market for oil products in Hawaii. ${ }^{290}$ The legislation, therefore, proceeded on the assumption that a significant market failure unique to Hawaii justified direct economic regulation. ${ }^{291}$ The primary question for the Court was whether "government regulation of private property 'effects a taking if [such regulation] does not substantially advance legitimate state interests . . ..",292

Justice O'Connor's opinion for the unanimous Court acknowledged that "our regulatory takings jurisprudence cannot be characterized as unified ...."293 She concluded, however, that the test applied in each of the controlling cases "focuses directly upon the severity of the burden that government imposes upon private property rights." ${ }^{294}$ Under this approach, the Takings Clause requires compensation for any physical

\footnotetext{
286. 544 U.S. 528 (2005).

287. Id. at 528. The Takings Clause reads "nor shall private property be taken for public use, without just compensation." U.S. CONST. amend. V.

288. See, e.g., Mark Fenster, The Takings Clause, Version 2005: The Legal Process of Constitutional Property Rights, 9 U. PA. J. CONST. L. 667, 726-44 (2007) (describing recent Supreme Court decisions concerning the constitutional aspects of property rights).

289. Lingle, 544 U.S. at 533.

290. Id. at 532-34.

291. See id. at 534 .

292. Id. at 531 (quoting Agins v. City of Tiburon, 447 U.S. 255, 260 (1980)).

293. Id. at 539 .

294. Id.
} 
taking because "permanent physical invasion, however minimal the economic cost it entails, eviscerates the owner's right to exclude others from entering and using her property-perhaps the most fundamental of all property interests." 295 But when regulation of property rights does not involve physical invasion, Justice O'Connor explained, the relevant inquiry "aims to identify regulatory actions that are functionally equivalent to the classic taking in which government directly appropriates private property or ousts the owner from his domain." ${ }^{296}$ Whether regulation effects a taking depends on "the severity of the burden that government imposes upon private property rights." ${ }^{297}$ Unless regulation operates as a "complete elimination of a property's value,"298 or falls within the special category of an impermissible land use exaction, ${ }^{299}$ the judicial "inquiry turns in large part, albeit not exclusively, upon the magnitude of a regulation's economic impact and the degree to which it interferes with legitimate property interests.",300

By respecting the sanctity of a property owner's right to exclude and at the same time using a discretionary balancing approach to judge nearly any other form of governmental interference with property, the Court evidenced a traditional theory: the constitutional notion of property protects the owner's absolute right to exclude others, but, through a deferential balancing test that empowers government to interfere with property rights in many other ways, it falls far short of enshrining property as an individual's right of "sole and despotic dominion." 301 The opinion offers no explicit economic analysis, although the unruly balancing standard opens the door to arguments based on the costs and benefits involved.

For present purposes, however, the most significant aspect of Lingel concerns the distinction that Justice O'Connor made between the takings issue and a due process challenge to government regulation of private property. A regulatory takings claim "presupposes that the government has acted in pursuit of a valid public purpose."302 Whether the regulation satisfies due process requirements "is logically prior to and distinct from

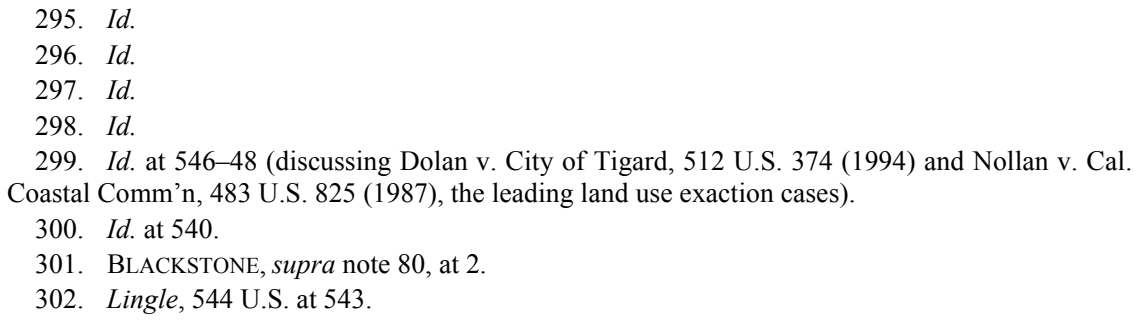


the" takings issue. ${ }^{303}$ With respect to the due process test, Justice O'Connor reaffirmed the Court's 1926 opinion in Village of Euclid $v$. Ambler Realty Co., ${ }^{304}$ "a historic decision holding that a municipal zoning ordinance would survive a substantive due process challenge so long as it was not 'clearly arbitrary and unreasonable, having no substantial relation to the public health, safety, morals, or general welfare." 305 By repeating and endorsing the Euclid substantive due process standard, Justice O'Connor again signaled that the constitutional notion of property adheres to the relatively subjective precepts of traditional theories, which view property as a fundamental individual right, in contrast to the more objective and quantifiable approach of economic analysis, which relates the right of property to efficiency.

Justice O'Connor's opinion in Lingle, however, also demonstrates that the Court recognizes the legislative prerogative to regulate private property rights based on economic principles. Indeed, the opinion adopted a distinctly deferential stance on the economic strategy of Hawaii's rent control legislation. ${ }^{306}$ A critical problem with the "substantially advances" formula, Justice O'Connor explained, was that "it would require courts to scrutinize the efficacy of a vast array of state and federal regulations - a task for which courts are not well suited. Moreover, it would empower-and might often require-courts to substitute their predictive judgments for those of elected legislatures and expert agencies." 307 While Lingle involved a takings challenge, the reasoning indicates that the Court will also reject any substantive due process approach that would overturn government restrictions on property rights based on a judicial calculation that the regulation is an ineffective device for achieving the legislative objective. This is most evident from the Court's criticism that, in passing on Chevron's claim, "the District Court was required to choose between the views of two opposing economists as to whether Hawaii's rent control statute would help to prevent concentration and supracompetitive prices in the State's retail gasoline market." 308 The trial court's error was not simply in misreading the Court's takings jurisprudence but, more fundamentally, in failing to recognize that courts must defer to legislative judgments about

303. Id.

304. 272 U.S. 365 (1926).

305. Lingle, 544 U.S. at 541 (quoting Vill. of Euclid v. Ambler Realty Co., 272 U.S. 365, 395

(1926) (emphasis added)).

306. See id. at 543-45.

307. Id. at 544 .

308. Id. at 544-45. 
the justifications for and efficacy of regulatory actions; the Court stated: "We find the proceedings below remarkable, to say the least, given that we have long eschewed such heightened scrutiny when addressing substantive due process challenges to government regulation." 309

The net effect of Lingle, therefore, is to preserve a traditional perspective on property at the judicial level even while validating an economic analysis of property in the legislative arena. ${ }^{310}$ For sustainability, the implication is that even when a court doubts that a legislative use of economic analysis or an economic instrument will be effective to achieve its intended purpose, the courts should respect the legislature's decision unless the resulting interference with private property rights is "clearly arbitrary and unreasonable, having no substantial relation to the public health, safety, morals, or general welfare." 311

The sharply contrasting opinions of the Justices in another 2005 Takings Clause case provide further evidence that traditional property theories persist in the twenty-first century and that the Court will give wide berth to legislative decisions, including those that reflect economic judgments. The Court granted certiorari in Kelo v. City of New London $^{312}$ to decide "whether a city's decision to take property for the purpose of economic development satisfies the 'public use' requirement of the Fifth Amendment." ${ }^{13}$ Justice Stevens wrote the majority opinion upholding the city's right to take residential property by eminent domain so that a private developer could use the property for commercial purposes that could bring economic benefits to the city. ${ }^{314}$ In determining "whether the City's development plan serves a 'public purpose,",315 Justice Stevens concluded: "Without exception, our cases have defined that concept broadly, reflecting our longstanding policy of deference to legislative judgments in this field." 316 In this way, the majority opinion reflects the familiar balancing approach of traditional property theory under which the individual's interest in private property,

309. Id. at 545 .

310. This is not to say that the Hawaii legislature necessarily applied a valid economic analysis, which is a question the Court completely avoided. See id.

311. Id. at 541 (quoting Vill. of Euclid v. Ambler Realty Co., 272 U.S. 365, 395 (1926) (emphasis added)).

312. 545 U.S. 469 (2005).

313. Id. at 477 .

314. Id. at $488-89$.

315. Id. at 480 .

316. Id. 
while strong, must often yield to the government's interest in advancing social welfare.

Justice Kennedy's concurring opinion in Kelo also evidenced a traditional perspective by providing a reminder that U.S. notions of property rights require vigilance against the tyranny of majority rule. ${ }^{317}$ Justice Thomas's strident dissent, which repeatedly cited to Blackstone's views on property, ${ }^{318}$ insisted not only that the Court's "modern reading" of the Public Use Clause ignored its "history and original meaning," 319 but also that a taking for economic development purposes is especially objectionable because it uniquely threatens the individual rights of the powerless. $^{320}$ This latter argument not only reflects a traditional property theory, but may even suggest hostility toward any economic analysis of individual property rights.

Justice O'Connor's dissent, in which Chief Justice Rehnquist, Justice Scalia, and Justice Thomas joined, more clearly reflects the traditional, intuitive reverence for the private property rights of individuals. Justice O'Connor's core objection was that if a governmentally endorsed economic development plan is a public use, then government may take whatever private property it might want. ${ }^{321}$ Her impassioned conclusion evoked a visceral impulse for the sanctity of private property as a matter of individual liberty: "The specter of condemnation hangs over all property. Nothing is to prevent the State from replacing any Motel 6 with a Ritz-Carlton, any home with a shopping mall, or any farm with a factory." 322 Her indignation on behalf of property owners without sufficient resources to defend their rights against those with "power in the political process" became palpable when Justice O'Connor complained: "The Founders cannot have intended this perverse result. '[T]hat alone is a just government,' wrote James Madison, 'which impartially secures to every man, whatever is his own.",323

What is most striking about the Lingle and Kelo cases is that all the opinions in both cases may be so easily reconciled with a traditional theory of property rights. The analysis behind the holdings in both cases

317. Id. at 493 (Kennedy, J., concurring). Justice Kennedy cautioned that "there may be categories of cases in which the transfers are so suspicious, or the procedures employed so prone to abuse, or the purported benefits are so trivial or implausible, that courts should presume an impermissible private purpose ...." Id.

318. Id. at 505, 508, 510 (Thomas, J., dissenting).

319. Id. at 514 .

320. Id. at $521-22$.

321. Id. at 494, 503 (O’Connor, J., dissenting).

322. Id. at 503 .

323. Id. at 505 . 
acknowledged property as a fundamental individual right while also recognizing that government has relatively broad power to interfere with private property in the interest of the public welfare. And in discussing the constitutional limits on the government's right to regulate or appropriate private property, none of the opinions used economic analysis explicitly, and none even hinted at any other alternative property theory. Indeed, the narrow but contentious dispute in Kelo concerned only the meaning of the Public Use Clause, a topic on which the justices' disagreements primarily reflected conflicting views on whether public use and public purpose are constitutionally equivalent notions.

\section{A Judicial Perspective on Sustainability as Public Policy}

Okeson v. City of Seattle, ${ }^{324}$ decided by the Supreme Court of Washington, arose when Seattle City Light, a municipal utility, adopted a plan to use an economic instrument to promote sustainability. ${ }^{325}$ Although the case did not involve private property, it addressed some key issues that will arise when sustainability programs impinge on property rights. Following the directives of the Seattle City Council, the utility implemented a plan to offset greenhouse gas emissions from its own operations by paying other generators of greenhouse gases to reduce their emissions. ${ }^{326}$ Utility ratepayers challenged the authority for the plan under Washington enabling statutes governing municipal utilities. ${ }^{327}$ While the ratepayers argued that the applicable statutes did not empower City Light to adopt the program, they conceded that combating global warming was a permissible government objective. ${ }^{328}$ The court went further and declared the purpose "a meritorious one." 329 In a significant endorsement of sustainability as public policy, the court also concluded "that the program may be viewed as a legitimate part of the utility's production of electricity because its purpose is to prevent City Light's production from causing a net increase in global greenhouse gas emissions . ..."330 On the ultimate issue, however, the court struck down the plan because it served a general government purpose rather than a

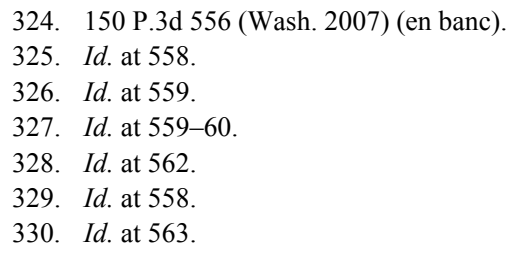


proprietary one under the utility enabling statutes. ${ }^{331}$ On that technical basis, the court held that the program could only be funded by the taxpayers at large rather than by utility customers in the form of a rate adjustment. $^{332}$

The debate over City Light's statutory power to implement its sustainability plan at ratepayers' expense parallels one of the most basic property rights questions about intrusive sustainability programs: are long-range, global concerns too uncertain and remote to justify interference with private property? "Here, the ratepayers argued that the required nexus is missing because global warming has only a slight and speculative impact, if any, on City Light's ability to supply electricity." "333 On this point, the court accepted the city's argument "that its authority for the offset contracts does not hinge on proving that a specific emission reduction somewhere on the globe translates into more snow melt flowing through the city's hydropower plants. It is not for us to evaluate the scientific merit of the city's offset contracts.",334

In acknowledging that the general governmental purpose of the plan was valid, the court implicitly accepted the city's determination, declared in a City Council resolution, that "global warming represents a clear and increasingly imminent danger to the economic and environmental health of the world, and to specific qualities of life for the Seattle area including water supply, hydroelectric energy production, air quality, forest health, species protection and recreational activities." ${ }^{335}$ Relying on the broad scope of the police power, ${ }^{336}$ courts can use a similarly deferential attitude to uphold legislative decisions that impose almost any restriction on private property rights for the sake of global sustainability.

Because the Okeson decision turned on the limited statutory powers of the utility, the holding does not determine the extent to which a general police power action to address global warming may require a nexus between the global harm and some local impact. But the concurring and dissenting opinions signal that this issue may be hotly debated in future cases. Concurring in the result, one of the justices offered this criticism of the majority's deference to the city's global objective: "On this record Seattle City Light's program of paying others

\footnotetext{
331. Id. at $558,563-65$.

332. Id. at 558 .

333. Id. at 563

334. Id. at 564 .

335. Id. at 558 .

336. See Hadacheck v. Sebastian, 239 U.S. 394, 410 (1915) (referring to the police power as "one of the most essential powers of government,- one that is the least limitable").
} 
not to emit greenhouse gases has about as much effect on global warming as making a bonfire out of ratepayers' hard-earned dollars.",337 A dissenting justice took the opposite view and argued that the emissions offset plan not only served a valid governmental purpose but that it was implicitly within the far more narrowly circumscribed powers of a public utility. ${ }^{338}$

The dissenting opinion in Okeson is especially relevant to the broader question of sustainability restrictions on private property. In arguing that the greenhouse gas mitigation plan bore a sufficient nexus to the utility's proprietary functions, Justice Owens advanced an economic analysis that could be applied equally to deflect a substantive due process attack against government regulation of private property to achieve sustainability. Recall that Lingle reaffirms that substantive due process condemns only those property regulations that are "clearly arbitrary and unreasonable, having no substantial relation to the public health, safety, morals, or general welfare." ${ }^{339}$ Justice Owens criticized the argument that even though Seattle City Light could properly pass along to ratepayers the costs of reducing greenhouse gas emissions at the utility's own facilities, it could not mitigate the effects of its operations by paying other operators to reduce their greenhouse gas emissions. ${ }^{340}$ In his view, "the Seattle City Council's required mitigation of [greenhouse gases] obliged City Light to internalize" ${ }^{341}$ the costs of its operations, which the utility could do "either by reduction of [greenhouse gases] at its own facilities or by purchasing offset credits from other facilities." ${ }^{\text {342 }}$ Justice Owens argued that the utility's mitigation plan was justifiable as "[t]he less expensive and more efficient internalization method." ${ }^{343}$ Using this economic analysis, he saw a "strong nexus between the offset program and City Light's express purpose of providing electricity. Because the ratepayers benefit from using the electricity generated by City Light, the ratepayers should pay the costs associated with such power generation." 344 Justice Owens argued that "promoting efficiency in energy generation is a proprietary purpose" 345 and that it was not for the

\footnotetext{
337. Okeson, 150 P.3d at 565 (Sanders, J., concurring).

338. Id. at 565-66 (Johnson, J., dissenting).

339. Lingle v. Chevron U.S.A., Inc., 544 U.S. 528, 541 (quoting Vill. of Euclid v. Ambler Realty Co., 272 U.S. 365, 395 (1926)).

340. Okeson, 150 P.3d at 565-66 (Owens, J., dissenting).

341. Id. at 567 .

342. Id.

343. Id

344. Id.

345. Id.
} 
court "to dictate the policies adopted by municipal corporations so long as those policies are constitutional and not arbitrary or capricious." 346

The Washington legislature agreed with Justice Owens's economic analysis. In a prompt response to the Okeson decision, the legislature authorized public utility districts to purchase emissions credits and to use other economic instruments to internalize the costs of greenhouse gas emissions resulting from their operations. ${ }^{347}$ A similar economic analysis could be used to justify governmental restrictions on private property rights enacted in the interest of sustainability.

\section{The Nascent Conflict Between Sustainability and Property Rights}

When read together, Kelo, Lingle, and Okeson forecast the approach courts will follow when facing a property rights attack on sustainable development controls, especially those governing land use. A land use regulation that bears a rational relationship to the public health, safety, or welfare will survive a substantive due process challenge. ${ }^{348}$ Moreover, the United States Supreme Court has repeatedly reaffirmed that it will defer to nearly any legislative determination that a proposed property regulation serves a valid police power purpose. ${ }^{349}$ Furthermore, when the contested government action merely regulates land use without physically interfering with possession, ${ }^{350}$ the adversely affected landowner will have no right to compensation in a takings claim absent a showing that the restriction "denies [the] owner economically viable use of his land"351 or that it imposes burdens that bear an insufficient relationship to the regulation's public benefits. ${ }^{352}$ In other words, unless the regulation virtually prohibits any valuable use of the land, courts will use a deferential balancing test to determine how far government regulation may go. ${ }^{353}$ In essence, this approach follows a traditional

\footnotetext{
346. Id

347. See supra note 278 and accompanying text.

348. Vill. of Euclid v. Ambler Realty Co., 272 U.S. 365, 395 (1926).

349. Kelo v. City of New London, 545 U.S. 469, 479-83 (2005).

350. Virtually any permanent physical invasion, no matter how minor, constitutes a taking. See Loretto v. Teleprompter Manhattan CATV Corp., 458 U.S. 419, 426-35 (1982) (holding that a state law that required the owner to allow attachment of cable facilities to a building was a taking).

351. Lucas v. S.C. Coastal Council, 505 U.S. 1003, 1016 (1992).

352. See Penn Cent. Transp. Co. v. City of New York, 438 U.S. 104, 124 (1978) (discussing several factors that courts consider).

353. A distinct line of takings cases applies when a land use authority conditions development approval on the owner's agreement to dedicate some use of the land to the public. See City of Monterey v. Del Monte Dunes at Monterey, Ltd., 526 U.S. 687, 702-03 (1999); Dolan v. City of Tigard, 512 U.S. 374, 390-91 (1994); Nollan v. Cal. Coastal Comm'n, 483 U.S. 825, 834-42 (1987).
} 
theory by recognizing that property rights are subject to reasonable limits. Ultimately, these principles strongly suggest that the U.S. Constitution should have a high tolerance for sustainable development regulations.

The constitutional analysis does not, however, end the inquiry. The conflict between the majority and the dissenting opinions in Okeson serves as a reminder that judicial interpretations may vary radically about how far specific enabling statutes authorize governmental bodies to go in the interest of sustainability. Moreover, when state or local governments seek to advance sustainability in ways that stretch traditional notions of the public health, safety, or welfare, state courts may apply their constitutions or the relevant enabling acts in ways that show greater deference to property rights than the U.S. Constitution requires. ${ }^{354}$

\section{EVAluating SustainABILITY AgENDAS IN Light OF PROPERTY THEORIES}

To what extent does sustainability require us to adjust our concepts of private property? Sustainability theory claims that those who exercise dominion over natural resources should do so only to the extent they can without consuming, exhausting, or injuring those resources. ${ }^{355}$ In other words, every owner is a steward of the natural capital over which he or she may exercise dominion. As a result, the theoretical tension between sustainability and private property stems primarily from the difference between ownership in usufruct (the temporary right to use property without diminishing its future value) and absolute ownership (the prototypical, Blackstonian fee simple). ${ }^{356}$

\footnotetext{
It is unclear whether or in what manner these exaction cases may limit the power of land use authorities to impose impact fees on developers to offset the presumed burdens that development imposes on future generations or the global environment. See generally JULIAN CONRAD JuERgENSMEyer \& THOMAS E. Roberts, LAND Use PlanNing AND DEVElopMent REgulation LAW 594-603 (2d ed. 2007) (discussing land use and preservation in the context of farmland).

354. See, e.g., County of Wayne v. Hathcock, 684 N.W.2d 765, 774-87 (Mich. 2004) (ruling contrary to the result in the Kelo case on state law grounds); Centene Plaza Redev. Corp. v. Mint Props., 225 S.W.3d 431, 433-35 (Mo. 2007) (en banc) (refusing to find that an area was blighted); Gallenthin Realty Dev., Inc. v. Borough of Paulsboro, 924 A.2d 447, 458-60 (N.J. 2007) (no authority to redevelop land that was not fully productive); City of Norwood v. Horney, 853 N.E.2d 1115,1123 (Ohio 2006) (invalidating statute on vagueness grounds and recognizing that economic benefits alone are not enough to satisfy the public use requirement); Board of County Comm'rs v. Lowery, 136 P.3d 639, 647-52 (Okla. 2006) (economic development alone is not enough to satisfy public use requirement of Takings Clause).

355. See discussion supra Part II.A.

356. See generally Ellickson, supra note 73 , at 1364, 1367-71 (discussing advantages and disadvantages of the two types of ownership).
} 
As Part II demonstrates, while property under the common law tradition presumes that ownership includes a right to consume or exhaust, that right has never been absolute. The concept of property, both under the common law and as modified by an array of legislative controls, recognizes many limits on the owner's freedom to use and enjoy. But the concept of property under United States law has not yet made significant accommodations specific to sustainability theory. In light of the urgent assertions of the sustainability movement, the time to re-examine property theory is here.

Before considering what modifications sustainability may demand of property theory, it is helpful to recognize that many important sustainability strategies impose no restrictions on private property. For example, even if the United States enters into international treaties that establish aggressive new national goals to reduce greenhouse gas emissions, implementing those goals will not necessarily require governmentally imposed restrictions on the ownership or use of private property. The most prominent green building strategies currently being implemented across the country to improve energy efficiency illustrate this point. Many of these programs introduce sustainable building practices primarily by adopting energy efficient building standards for governmental buildings and operations and only incidentally by encouraging, without requiring, the private sector to adopt similar standards. ${ }^{357}$ While some sustainability measures impose green building standards on private development, others suggest that the government need only provide research support, educational programs, and incentives to help the private sector explore the business case for voluntarily adopting more sustainable construction and building operation practices. $^{358}$ If green building legislation goes only this far, it will require no adjustment to our concept of private property.

At what point might sustainable development standards lead to conflicts with property rights? The answer depends to a great extent on the theoretical underpinnings one posits both for the sustainability agenda and for the strong commitment under U.S. law to the institution of private property. While the cases explored in Part IV.B offer a roadmap for the analysis, it is a map that allows for alternate routes based on the competing theories of property and sustainability discussed throughout this Article. As noted in Part IV.A, when a resource conservation objective justifies a sustainable development strategy, the

357. See Circo, supra note 44 , at 754 .

358. Id. at 762-65. 
resulting restrictions on private property generally should raise only the same theoretical considerations that ordinary environmentalism present. Indeed, as Part III demonstrates, all of the dominant property theories tolerate significant restrictions on private property rights in the name of resource conservation. While the law and economics literature supports a vigorous debate about the proper approach for determining what degree of environmental regulation is optimally efficient, even the most strident advocates of a free market recognize the possibility that market failures sometimes require regulation in the name of environmental conservation. ${ }^{359}$ As the theoretical framework of sustainability shifts to generational justice or social justice, however, the potential for conflict intensifies to a greater or lesser extent depending on which property theory is applied. The remainder of this Article explores how the different strains of sustainability theory may require adjustments to each of the property theories considered in Part III.

\section{A. Sustainability and Traditional Property Theories}

As already suggested, sustainability as resource conservation presents essentially the same issues for traditional property theories as does conventional environmental protection. The police power is sufficiently broad to authorize government to impose reasonable restrictions on property rights in the name of resource conservation. The leading land use cases reflect the traditional theory that government may impose significant, even highly intrusive, restrictions on property rights for police power purposes. ${ }^{360}$ The usual test is that a police power imposition on property rights is valid unless it is "clearly arbitrary and unreasonable, having no substantial relation to the public health, safety, morals, or general welfare." 361 Notice the two elements involved: the limitation on property rights must be for a valid police power function (health, safety, morals, or general welfare) and the limitation imposed must bear at least some relationship to that police power purpose (must not be arbitrary or unreasonable). While this standard recognizes property as a fundamental individual right, it also yields to expansive governmental authority to enact property rights restrictions at the federal,

359. See, e.g., Jonathan H. Adler, Free \& Green: A New Approach to Environmental Protection, 24 HARV. J.L. \& PUB. POL'Y 653, 658-59 (2001) (noting "that there is no question that the early environmental laws seemed to work... principally because [they were] plucking low-hanging fruit").

360. See supra notes $286-323$.

361. Vill. of Euclid v. Ambler Realty Co., 272 U.S. 365, 395 (1926). 
state, and local levels in the name of resource conservation. This familiar approach that balances competing individual and governmental interests ultimately leaves it to courts to determine on a case-by-case basis whether a resource conservation measure goes too far. While it may be difficult in a particular circumstance to predict what result a balancing standard will produce, sustainability in this relatively weak sense requires no adjustment to traditional property theory.

What of sustainability programs that go beyond a resource conservation motive to promote generational justice? The agendas of these programs may raise an issue not inherent in conventional environmental regulation: to what extent is equity between the current generation and indefinitely remote generations a legitimate police power objective? While the proposed purpose may be novel in the sense that the most familiar police power actions generally address present risks to the public welfare, it is not significantly more ambitious than many other purposes that have survived judicial scrutiny. ${ }^{362}$ Conventional environmental protection programs already recognize preservation of the natural environment as a valid police power goal. For decades, state and federal legislatures and courts have applied traditional property theories in ways that recognize broad discretion for government to adopt rules and restrictions affecting private property in the perceived interest of public welfare. ${ }^{363}$ Programs enacted at the dawn of the modern environmental protection era already seek long-term environmental preservation. ${ }^{364}$ There is little reason to expect legislatures and courts to be more skeptical about resource conservation strategies simply because they emphasize the interests of future generations. The Supreme Court of Washington's Okeson decision, discussed in Part IV.B, illustrates this perspective by holding that "combating global warming is a general government purpose."365 While that case involved the statutory authority of a public utility rather than government regulation over private property rights, the holding indicates that, at least in some states, sustainability in the sense of generational justice should be a valid police power purpose.

362. See Kelo v. City of New London, 545 U.S. 469, 485 (2005) (holding that economic development qualifies as a public use for eminent domain purposes); Lingle v. Chevron U.S.A. Inc., 544 U.S. 528, 543-45 (2005) (declining to review the effectiveness of a state rent control law).

363. See supra notes $286-323$.

364. See generally Lebster B. Lave, The Strategy of Social Regulation: Decision FRAMEWORKS FOR POLICY (1981), as reprinted in REVESZ, supra note 18, at 85-89 (examining different frameworks employed to make environmental regulatory decisions).

365. Okeson v. City of Seattle, 150 P.3d 556, 558 (Wash. 2007) (en banc). 
It is far less likely that traditional property theories will tolerate governmental strategies justified primarily by the social justice goal of distributive equity, especially when the legislative objective goes beyond the interests of current and future residents of the geographic region over which the enacting body exercises authority. The problem here is that distributive justice does not figure prominently in either the legislative or the judicial bases for current environmental protection laws in the United States. ${ }^{366}$ As already noted, the traditional property theories recognized in this country emphasize that individual property rights are subject to reasonable limitations in the interest of the general public welfare, but they do not generally speak to equity in the allocation of resources, and some theorists forcefully argue that our traditional property theories inherently support property inequality. ${ }^{367}$ Sustainability objectives that serve the interests of social justice, especially at the global level, seem to require significant deviations from traditional perspectives.

\section{B. Sustainability and Economic Property Theories}

Through its singular emphasis on efficiency, the law and economics literature offers abundant principles for validating or rejecting resource conservation programs. ${ }^{368}$ There is no inherent clash between economic analysis and sustainability as resource conservation. The economic analysis may, however, sometimes provide a different result than will traditional property theory because cost-benefit analysis of resource conservation strategies uses more objective and quantifiable tests than the balancing-of-interests standard of traditional property theory. Additionally, economic analysis generally does not support direct government regulation of property rights if the marketplace (regulated or unregulated) can achieve the maximum social welfare. ${ }^{369}$ In the absence of significant market failures, economic theory posits that if resource conservation contributes more quantifiable value than the costs it imposes, there will often be no need for the government to regulate private property rights. ${ }^{370}$ Part III.B has already surveyed the basic

366. See generally discussion supra Part IV.

367. See supra notes $255-61$ and accompanying text.

368. See Circo, supra note 44, at 764-65 ("Existing research offers much on the impact of government regulations in general and more specifically on the efficacy of current environmental laws and policies." (footnote omitted)).

369. Adler, supra note 359 , at 661-76; see Wesley A. MAgat \& W. KIP VISCUSI, INFORMATIONAL APPROACHES TO REGULATION (1992), reprinted in REVESZ, supra note 18, at 14950 (arguing for "informational remedies ... rather than command-and-control regulation").

370. See Adler, supra note 359 , at 671 ("empirical evidence shows quite clearly that ecological 
economic tenets involved-individual property owners acting in their own distinct interests may bargain to the optimal result to achieve the greater efficiency of resource conservation, but if transaction costs are high, or other market inefficiencies exist, some form of regulation may be appropriate. Unlike traditional property theory, however, economic analysis offers sophisticated tools to help policy makers determine what specific restrictions or regulations affecting private property are justified —or, most efficient. ${ }^{371}$

It is more difficult to judge whether economic analysis accommodates sustainability programs based on generational justice. Perhaps the fact that future generations do not interact with the current generation means that an economic approach cannot address the interests of multiple generations. But some theorists argue that the economic perspective inherently weighs the interests of future generations appropriately. For example, Ellickson argues that "the preeminent advantage of an infinite land interest is that it is a low-transaction cost device for inducing a mortal landowner to conserve natural resources for future generations." $372 \mathrm{He}$ goes on to extend this proposition to its most extreme conclusion by claiming that "benefits and costs from here to eternity are capitalized" 373 into the marketplace calculations of the selfinterested actor. Ellickson offers this explanation for his astounding claim:

Although the assertion may seem counterintuitive, the key to land conservation is to bestow upon living persons property rights that extend perpetually into the future. The current market value of a fee in Blackacre is the discounted present value of the eternal stream of rights and duties that attach to Blackacre. A rational and self-interested fee owner therefore adopts a [sic] infinite planning horizon when considering how to use his parcel, and is spurred to install cost-justified permanent improvements and to avoid premature exploitation of resources. The fee simple in land cleverly harnesses human selfishness to the cause of altruism toward the unborn, a group not noted for its political clout or bargaining power. ${ }^{3}$

While this logic holds some appeal for decisions that affect future periods within the immediate consciousness of current property owners,

\footnotetext{
concerns are better cared for when incorporated into market institutions through property rights and exchange than left dependent upon government beneficence for protection").

371. See Circo, supra note 44, at 762-65.

372. Ellickson, supra note 73, at 1368.

373. Id. at 1369 .

374. Id. (footnotes omitted).
} 
it fails in the face of the much longer horizons of generational justice sustainability. Even if current land prices capitalize residual land values for several future generations, it overstates the practical bounds of rational calculation to conclude that they do so perpetually. Not even the most sophisticated buyers of real estate today can acquire the information needed to adjust future values to reflect ecological degradation threatened many generations into the future. Moreover, as discussed more fully below, ${ }^{375}$ even if we assume that this information is available, we have no standards for selecting a rational discount rate to establish the present value of reduced income streams for distant generations. ${ }^{376}$

Consider how the market actually prices a parcel of income producing real estate. A discounted cash flow valuation analysis only requires a few years' worth of reasonably reliable revenue projections to establish an acceptable present value of the asset that will produce those cash flows. ${ }^{377}$ In other words, the perpetual discounting assumption does not reflect how rational bidders for income producing assets actually behave in current market transactions. And even if an investor today considers infinitely remote revenue streams, discount rate considerations support substantially equal present values for two different parcels if they are distinguishable only by their presumed future income potentials at a point in the too distant future. ${ }^{378}$ The reason that global warming has the attention of rational investors today is not that the marketplace capitalizes projected costs and benefits "from here to eternity.",379 Rather, it is because, after decades (or more) of gradual degradation, global warming finally threatens to impose significant costs in the near term rather than only many generations hence.

In addressing this problem, Posner recognizes that one of the most nettlesome issues for the economist concerns selecting an appropriate discount rate, which is essential to any cost-benefit analysis involving an environmental protection cost incurred today to gain an environmental benefit in the distant future. Posner discusses three possible solutions:

375. See infra notes $380-84$ and accompanying text.

376. See COLE \& GROSSMAN, supra note 125 , at 325-28 (evaluating discount rates).

377. See Mike E. Miles et al., Real Estate Development: Principles and Process 208 (4th ed. 2007) (using five years of data).

378. Standard present value analysis illustrates this point. The present value calculation is: Present Value = Future Value X $1 /(1+\mathrm{i})^{\mathrm{n}}$, where " $\mathrm{i}$ " is the discount rate and " $\mathrm{n}$ " is the number of discount periods (future years for our purposes). The present value of a series of future cash flows is simply the total of the present values of all of the individual future cash flows. Id. at 208. As the exponent value increases for the number of periods involved (say, $n=300$ years), the distant future value eventually approaches zero, and it will have no measurable effect on the calculation of the real estate's present value.

379. Ellickson, supra note 73, at 1369. 
One is to use a zero discount rate on the ground that we have no right to value the welfare of future generations any less than we value our own welfare. But even if the premise is accepted, the conclusion does not follow, for it ignores the possibility of investing the money that we would need to implement the regulation and using the interest to fund a future project. ${ }^{380}$

The second approach would be to use a commercial discount rate, which would allow the current generation to compare the costs of investing today for the benefit of future generations to the benefits of current consumption. ${ }^{381}$ Because that alternative allows the current generation to act selfishly, the third alternative is to make the decision a political one:

If the government decides that people are being too selfish in deciding how much to spend today for the benefit of future generations, it can pick a discount rate for use in cost-benefit analysis of its projects that is lower than the commercial interest rate; this will automatically weight the future more heavily than the market does. ${ }^{382}$

But this approach may lead to an inefficient decision to make current expenditures that would be better invested in a capital fund for future generations.

Based on the discount rate problem alone, it may well be that present value analysis cannot adequately address the generational justice objective. The current generation has insufficient information to select from a wide range of defensible discount rates, from zero (a benefit in the distant future has the same value as a more immediate benefit) to an abnormally high rate (the more remote the future benefit is, the less current investment it justifies). But there is an even more troublesome problem with using economic analysis to decide whether to address future ecological harm now or in the future: economic analysis cannot predict the extent to which, at any cost, "natural capital can be increased through human activities." 383 While environmental economists have recently proposed intriguing theoretical models for valuing natural capital, ${ }^{384}$ at least for now, economic analysis does not seem to have the tools needed to administer a sustainability agenda based on generational justice.

\footnotetext{
380. POSNER, supra note 137, at 399.

381. Id

382. Id.

383. Geldrop \& Withagen, supra note 20 , at 452.

384. See, e.g., id. at 447-50 (proposing a model for valuing natural capital); England, supra note 20 , at 259-62 (attempting to measure natural capital).
} 
To the extent that social justice, rather than generational justice, provides the theoretical basis for sustainability, current economic analysis seems even less adaptable. This is because distributive justice, at least when based on a Rawlsian notion, ${ }^{385}$ is largely exogenous to the usual economic analysis. ${ }^{386}$ And even if some schools of economic analysis concede that a regime may properly seek social justice, the economic approach may still prefer property rules that maximize total social welfare without regard to distributive justice. ${ }^{387}$ After crafting a property system for that singular purpose, society may then use other devices, such as a taxing strategy or welfare programs to redistribute wealth, but only if those devices will not have the effect of reducing total social wealth. ${ }^{388}$ This seems to suggest that sustainability based on social justice, especially of the global variety, is incompatible with the dominant applications of an economic analysis of law that currently influence the scholarly literature on U.S. law. In sum, a social justice model of sustainability implies highly problematic adjustments in the economic analysis of property.

\section{Sustainability and Relational Property Theories}

Whether founded on resource conservation, generational justice, or social justice, sustainability seeks a property regime that is less tied to concepts of individual liberty than are the tenets of either the traditional or the economic theories of property. ${ }^{389}$ Moreover, sustainability promotes a stewardship vision that seeks to impose obligations on those who control resources by emphasizing their relationships with other inhabitants of the earth, both current and future. ${ }^{390}$ By its nature, sustainability promotes a collectivist value system that incorporates a third-world perspective. ${ }^{391}$ All of these characteristics of sustainability tend to be more consistent with a relational framework than they are with either the traditional or economic theories of property. ${ }^{392}$

385. See supra notes $224-38$ and accompanying text

386. See POSNER, supra note 137 , at $473-75$. While Posner does not completely dismiss the Rawlsian principles of justice, he finds them too indeterminate to solve problems: "Rawls's theory of distributive justice has no operational content." Id. at 474.

387. See SHAVELL, supra note 127, at 11-22 (discussing economic justification for property rights).

388. Id. at 654-60; Ellickson, supra note 73, at 1357.

389. See discussion supra Part II.A.3.

390. See Engel, supra note 14, at 2-9 (discussing ethics in conservation and development).

391. Id. at 15 .

392. See discussion supra Part III.C. 
The special connection between sustainability and relational tenets of property is least evident when sustainability derives solely from resource conservation, because that relatively weak form of sustainability merely argues that those who control natural resources today should avoid wasting or unreasonably degrading those resources to the detriment of future generations. Resource conservation does not necessarily require a relational perspective on property ownership except in the same sense involved in the traditional areas of nuisance law ${ }^{393}$ or land use controls. ${ }^{394}$ In other words, while a relational framework is receptive to resource conservation, it is no more so than are the traditional and economic property theories.

By contrast, generational justice insists that the current occupants of this earth must preserve the earth's natural capital for future generations. $^{395}$ In effect, generational justice argues for limited individual property rights based on the usufruct model rather than the fee simple model of the traditional and economic theories of property. ${ }^{396}$ Ownership in usufruct should be a comfortable concept for those relational theories that argue that control over property creates relationships that produce duties as well as rights. Therefore, the relational principles advanced by such theorists as Singer and Nedelsky should be particularly helpful to the generational justice basis of sustainability because they argue that a property regime should not only create rights in the owner but also should impose obligations toward those affected by the owner's control over and use of property. ${ }^{397}$

Finally, a relational approach is far more compatible with a social justice framework of sustainability than is any other property theory. In contrast to the traditional and economic perspectives, many relational theories embrace distributive justice principles. ${ }^{398}$ In keeping with ideals of distributive justice, a relational approach to property rights argues that because individuals acquire and exercise property rights in social contexts rather than in isolation, the interrelationships among members of society attach duties to property rights for the collective benefit of the social institutions in which those rights exist. As a result, a relational theory can conceive of the autonomous individual as a citizen who may have spatially global and temporally perpetual stewardship

393. See supra notes 116-22 and accompanying text.

394. See supra notes 293-323 and accompanying text.

395. See discussion supra Part II.A.2.

396. See supra notes 19-24 and accompanying text.

397. See supra notes 244-61 and accompanying text.

398. See supra notes $221-23$ and accompanying text. 
responsibilities. What is even more important is that a relational perspective can be used to argue that property rights at a base level are a matter of human rights. If every person, without regard to time or place, deserves that level of property essential for human dignity, significant restrictions on the property rights of the relatively wealthy may be necessary to secure and protect human rights for all persons throughout all geographic regions and socio-economic circumstances and for all generations. Nedelsky, for example, argues that both traditional and economic theories improperly link individual liberty or autonomy with the jealous protection of private property rights. ${ }^{399}$

\section{CONCLUSION}

Does sustainability challenge the U.S. property regime? The answer is yes, but in incremental ways that differ significantly depending on the underlying theoretical justification offered for sustainability. Sustainability as resource conservation may be easily reconciled with both the traditional property framework that still prevails in judicial analysis and with the economic analysis that now dominates in many academic circles and that heavily influences the legislative arena. Additionally, traditional property theory may be sufficiently malleable and subjective to accept a generational justice basis for sustainability. By contrast, whether or not an economic analysis of property will recognize generational justice depends on the current and future work of economists on complex topics such as valuing natural capital. Overall, the concept of property in the United States embodies sufficiently eclectic perspectives to accommodate much that sustainability demands. But what are the prospects in this country for a sustainability agenda based on social justice? Neither the traditional nor the economic approaches to property seem receptive. While relational property theories embody principles more consistent with a social justice model of sustainability, relational theories remain marginal in both our judicial and legislative processes.

These conclusions suggest that effective sustainability programs and strong property rights can coexist in the United States, but not necessarily at the level the international sustainability movement promotes. The critical question is whether U.S. sustainability advocates can muster the theoretical support they need to achieve their social justice objectives. For now, at least, it seems they cannot.

399. See supra notes $254-61$ and accompanying text. 